\title{
Between Creativity and Pragmatism: A Structural Analysis and Quantitative Survey of Federal Competitions for Yugoslav Monuments and Memorial Complexes (1955-1980)
}

Horvatinčić, Sanja

Source / Izvornik: Modern and Contemporary Artists' Networks. An Inquiry into Digital History of Art and Architecture, 2018, 124 - 165

Book chapter / Poglavlje u knjizi

Publication status / Verzija rada: Published version / Objavljena verzija rada (izdavačev PDF)

https://doi.org/10.31664/9789537875596.06

Permanent link / Trajna poveznica: https://urn.nsk.hr/urn:nbn:hr:254:617158

Rights / Prava: In copyright/Zaštićeno autorskim pravom.

Download date / Datum preuzimanja: 2023-04-26

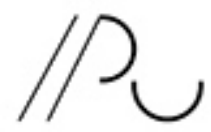

INSTIIUTZR FOVIJESTUMJETNOSII
Repository / Repozitorij:

PODEST - Institute of Art History Repository

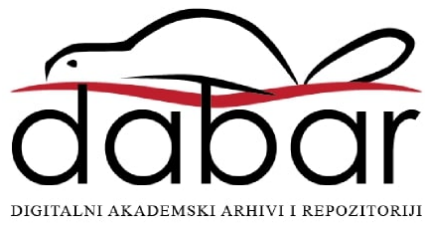



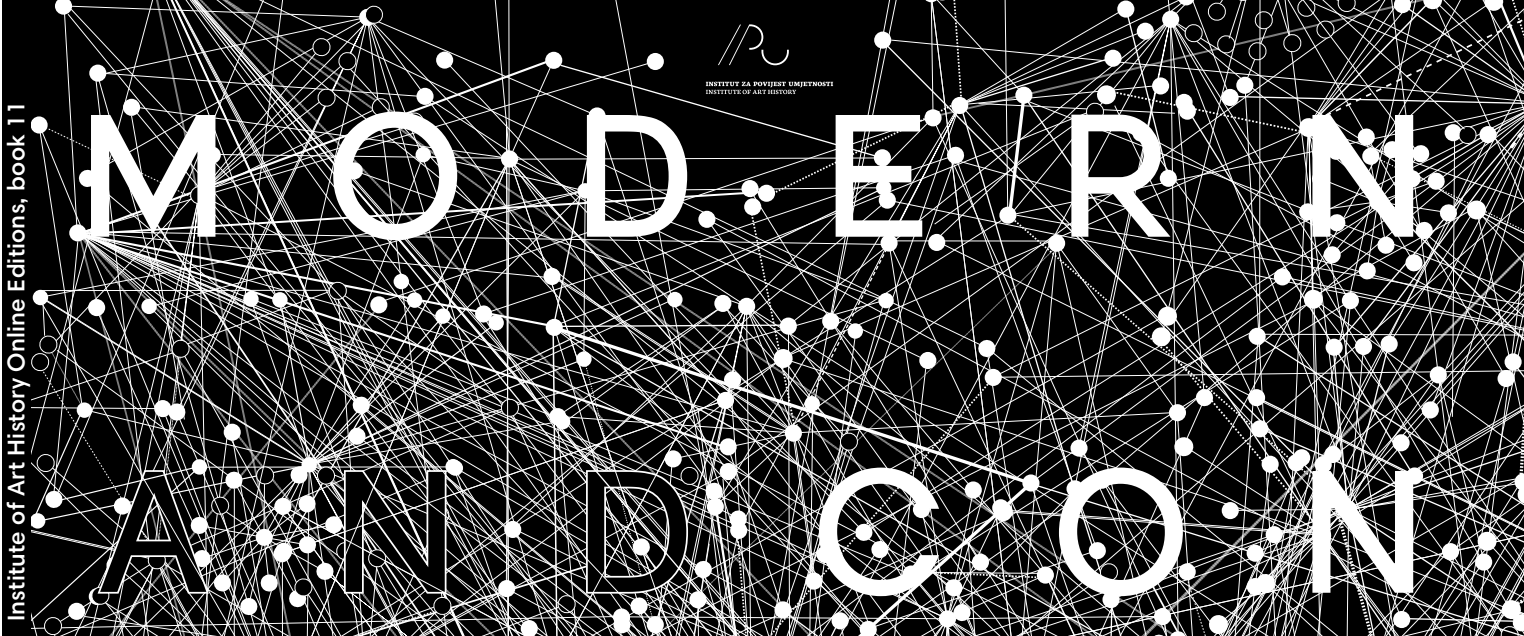

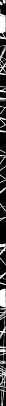

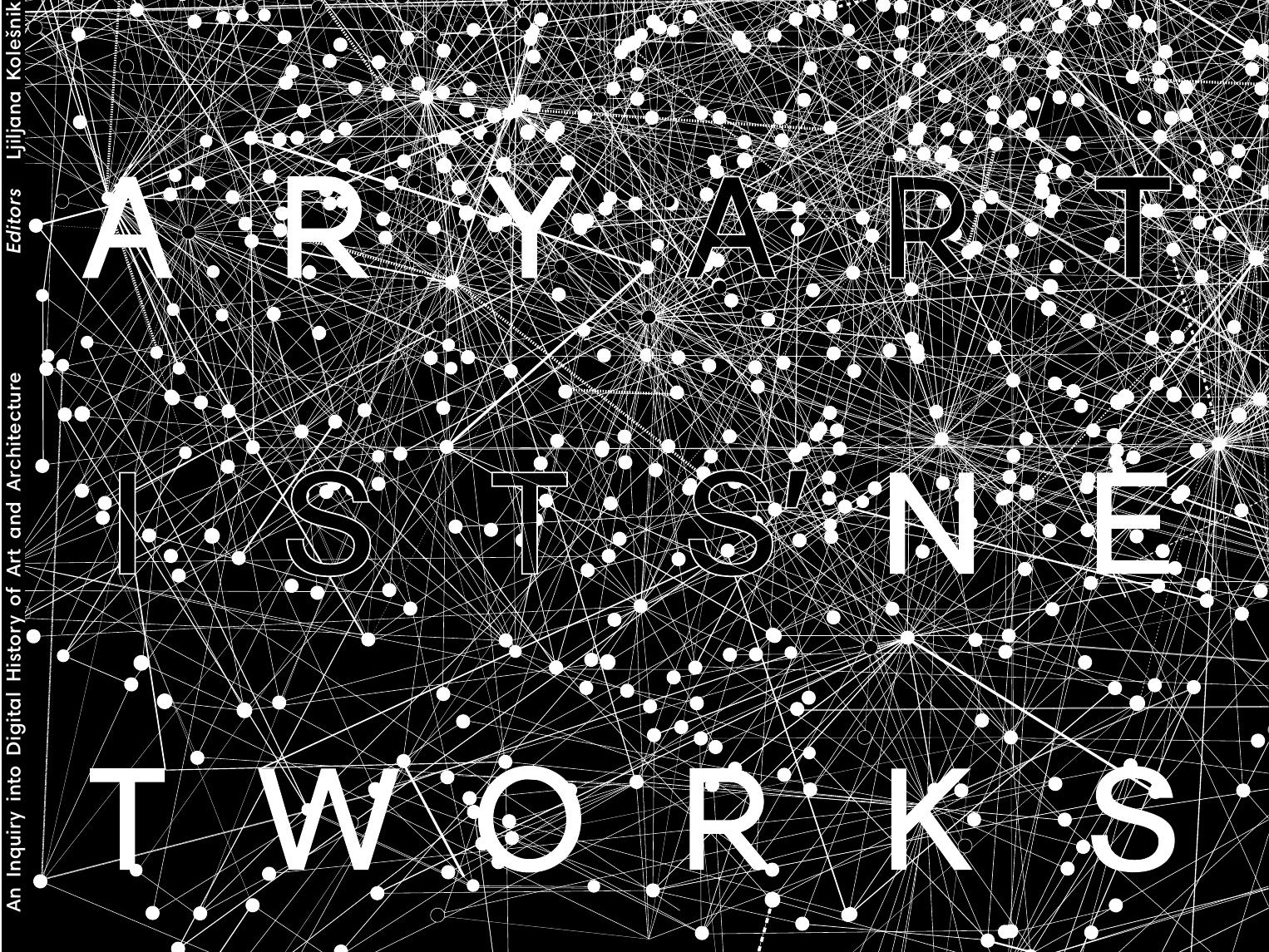


NETWORKS.

An Inquiry into Digital History of Art

and Architecture

Ljiljana Kolešnik

Editors

Ljiljana Kolešnik and

Sanja Horvatinčić

Sanja Horvatincic

Between Creativity and Pragmatism: Structural Network Analysis and Quantitative Survey of Federal Competitions for Yugoslav Monuments and Memorial Complexes (1955-1980)

\section{Hrzz

Željka Tonković, Sanja Sekelj

Duality of Structure and Culture: A Network Perspective on the Independent Cultural Scene in Zagreb and the Formation of the WHW Curatorial Collective

This book is the result of the research conducted within the project ARTNET (IP201311/6270) supported by the Croatian Science Foundation.

Contributors

Literature, archival and online sources 
mpetitions for Yugoslav Monuments and Memorial Complexes (1955-1980)

DOI: https://doi.org/10.31664/9789537875596.06

Public competitions for monuments and memorials have always attracted the at tention of historians of art and architecture whether due to the formal innovations and/ or visionary concept they tend to generate, or their role in establishing new standard and procedures for the evaluation and selection of public art and architecture. Needless to say, some of the major international public competitions and their winning projects, such as that for the Un known Political Prisoner in Berlin (1953), or the competitions for monuments commem orating victims of the Holocaust in the former Nazi concentration camps in Germany and Poland, ${ }^{227}$ have become indispensable references in the history of the post-wa modernism, and important case studies for studying underlying mechanisms of Cold War cultural politics. ${ }^{228}$ More recently, public

227 See, for example, literature on the Monument to the Victims of Fascism in Auschwitz: Katarzyna MurwaskaMuthesisus, "Oskar Hansen and the Auschwitz Countermemorial, 1958-1959," in Figuration/Abstraction: Strategies for Public Sculpture in Europe, 1945-1968, ed. Charlotte Benton (London: Ashgate Publishing Limited; Henry Moore Institute, 2004), 193-211. For competitions for the international memorial in Dachau, see: Andrea Ridle, and Lukas Schretter, eds. Das internacionale Mahnmal von Nandor Glid. Idee, Wettbewerbe, Realisirung (Berlin: Metropol-Verlag, 2015).

228 See, for example: Joan Marter,

"The Ascendancy of Abstraction for Public Art: The Monument to the Unknown Political Prisoner Competition," Art Journal. Sculpture in Postwar Europe and America 1945-1959, vol. 53, no. 4 (1994): 28-36; Robert Burstow, “Western European Modernism in the Service of American Cold-War Liberalism." In Art and Ideology:
Vietnam War Memorial in the United States, and the growing number of memorials to Holocaust victims and victims of "totalitarianism" in Europe and North America, have played a significant role in tackling contemporary relationships between aesthetic and political concerns. ${ }^{229}$

If research on 20th-century architectural competitions - itself a relatively young field of academic enquiry ${ }^{230}$ - is still pre dominantly focused on the big centres in

The Nineteen-Fifties in a Divided Europe, ed. Ljiljana Kolešnik (Zagreb: Društvo povjesničara umjetnosti Hrvatske, 2004), $37-56$.

229 See, for examples: Peter Carrier "Memorial fixation. The Monument for the murdered Jews of Europe in Berlin," Život umjetnosti, no. 64 (2001): 118-131; Peter Carrier, "Anti-Totalitarian Rhetoric in Contemporary German Politics (Its Ambivalent Objects and Consistent Metaphors)," Human Affairs, no. 21 (2011): 27-34. DOI: $10.2478 / \mathrm{s} 13374-011-0004-x$. 230 The academic interest for an analytic approach to this topic appeared in the late 1980s to early 1990s. See, for example: Helene Lipstadt: The Experimental Tradition: Essays on Competitions in Architecture (Princeton Architectural Pr, 1989). One of the reasons for such interest in that particular time period "may be found in the deregulation and market orientation of the building constructions sector during the 1980s and the reregulation in the 1990s through the European Parliament and Council directive". Jonas E. Andersson, Gerd Bloxham Zettersten, and Magnus Rönn, "Editors' Comments," in Architectural Competitions - Histories and Practice, ed. Jonas E. Andersson, Gerd Bloxham Zettersten, and Magnus Rönn (The Royal Institute of Technology and Rio Kulturkooperativ, 2013), 7-8. 
the West, ${ }^{231}$ the scope of knowledge on the specific niche of war memorial competitions is even more limited, or more tightly embedded into grand-narrative schemes. The history of the commissioning and production of post-WWII monuments and memorials, especially those related to wartime events that are tasked with embodying and transferring traumatic experience and social memory, serve as imprints of cultural, political and social issues of the Cold War era. In this regard, a comprehensive survey of international competitions for monuments, and their role in cultural and political exchange and networking, could be especially useful.

However, in South-Eastern Europe, the potential for architectural competitions to become the subject of academic research has only recently been recognized. In former Yugoslavia, competitions for monuments were mostly dealt with through individual case studies. ${ }^{232}$ More systematic and problem-oriented approaches have been pioneered only recently. ${ }^{233}$ Not only

231 See, for example, the index and the timeline of the 202 cited competitions in the publication: Chupin, JeanPierre, Carmela Cucuzzella and Bechara Helal (eds). Architecture Competitions and the Production of Culture, Quality and Knowledge: An International Inquiry. Potential Architecture Books Inc., 2015, 133-141.

232 See the texts published in the thematic volume Anali Galerije Antuna Augustinčića, no. 32-33; 34-35 (2015). 233 See: Grozdana Šišović: Architectural Competition Practice and the Issue of Autonomy of Architecture, PhD Thesis (Belgrade: University of Belgrade Faculty of Architecture, 2016); Tamara Bjažić Klarin: Arhitektonski i urbanistički natječaji između dva svjetska rata (1918.-1941.) - slučaj Zagreb (Zagreb: Institute of Art History, 2018). do such surveys reveal forgotten artistic and architectural projects, but they broaden our knowledge on the "history of ideas", and open up new perspectives on the cultural and political circumstances that conditioned the acceptance or refusal of innovative concepts. Such research is, however, encumbered by various practical obstacles. The models and drawings for competition entries have not always been preserved, mainly because their authors (especially visual artists), immersed in the spirit of the forward-looking progress of modernism, were at the time often unaware of their importance, or simply uninterested in the process of self-archiving. Another important obstacle is the lack of institutional upkeep of the documentation for competitions. This issue is especially pertinent in the local context, which - largely due to political reasons - has undergone drastic infrastructural changes since the 1990s, being exposed to the negative social attitudes to the legacy of post-war modernism, especially its more ideologically overt segments, such as monuments and memorials from the socialist era.

The present study, however, takes a different path in an effort to approach this complex, yet crucial, segment of the modernist production of the second half of the 20th century. Instead of analysing individual competition proposals, the aim is to approach the phenomenon of federal public competitions for monuments as platforms for social networking and exchange, and as a source of valuable statistical data that can outline the overall configuration of high-level memorial production in Yugoslavia. In other words, the aim of this paper is not to discuss the artistic and architectural achievements of awarded competition entries, but to outline and discuss the structural parameters of the very system that conditioned the production of memorials in the given context. The basic tenets of the present approach rely on the idea that the production of monuments in the period of Socialism in former Yugoslavia was a dynamic process, defined by different practices present in various levels of production, involving diverse socia agents with distinctive roles and dynamic interrelations. ${ }^{234}$ These processes were directed and managed by various federal, republic or local organizations, or individua stakeholders, whose actions and decisions on collective commemorative activities, including the construction of monuments, were conditioned by available material resources and guided by legal regulations. Different models and levels of production constantly coexisted and merged throughout the socialist period, resulting in various scales, types and degrees of formal and/ or morphological innovation. In order to understand the overall system of production and its artistic and architectural achievements, historians should - as fully and a comprehensively as possible - take into account and understand the interaction and relations between various and numerous actors participating in these processes. Due to the obvious limitations regarding reconstruction of an all-encompassing socia network of these processes, this analysis is focused on examining a clearly detectable and fixed segment of the said production defined by the same legal framework, and a limited number of involved actors - namely, the federal public competitions, and the networks of its jury members and awarded participants.

The methodology applied in this case study challenges the predominant approach to authorship in the field of production of

234 See Chapter 2 of the doctoral dissertation on memorial production in Croatia. Sanja Horvatinčić, "Spomenici iz razdoblja socijalizma u Hrvatskoj - prijedlog tipologije" (Zadar: University of Zadar, $126 \quad 127 \quad 2017), 47-152$ ponuments in Yugoslavia. Instead Pof formal aspects of particular realized projects, the combination of historiographical research and the results of quantitative and network analysis aims to analyse what was happening 'behind the scenes': What were the mechanism and who were the actors that enabled the production of the phenomenon referred to as 'Yugoslav monuments'? Apart from their common historical and ideological references, what else contributed to the notion of shared heritage associated with these objects today? ${ }^{235}$ What were the main features of awarded participants and jury members in terms of their gender, profes sion, place of origin, and what can this data tell us about the function of federal competitions for monuments in Socialist Yugo slavia? One particularly important aspect of this analysis is the equal treatment of jury members, that is, acknowledging thei active role in the field of memorial production, and their introduction to the (hi)story o monument-making. This very notion opens up new perspectives on several importan issues regarding the physiognomy of the whole field and the structural roles of certain central figures within the system: How were the roles of the two different types of involved actors - those of the competito and the evaluator - distributed, and what can we learn from their conflicting position within the system? What are the implications of the fact that one of the most prominen and important authors of monuments in Socialist Yugoslavia appears as the central figure in jury member networks? What

235 See the analysis on the notion of shared heritage in contemporary heritage management practices in former Yugoslavia: Marija Jauković, "To Share or to Keep: The Afterlife of Yugoslavia's Heritage and the Contemporary Heritage Management Practices," Politička misao: časopis za politologiju, Vol. 51 No. 5 (2014): 80-104. 
does the fact that the proportion of women among the awarded projects' teams is higher than the average seen in the field of memorial production mean?

However, while trying to answer the above questions, the primary aim of this case study is not to provide definitive conclusions, but to test the possibilities, and indicate the pros and cons of quantitative and network analysis when it comes to relatively small datasets on temporally and spatially limited historical phenomena.

TOWARD A QUALITATIVE ANALYSIS: A BRIEF HISTORY OF FEDERAL COMPETITIONS FOR MONUMENTS IN SOCIALIST YUGOSLAVIA

An anonymous public competition is a democratic procedure through which communities aim to secure the most aesthetically and functionally adequate solutions for objects of common or public interest. Apart from the rebuilding of the war-devastated country, one such interest in post-war Yugoslavia was the construction of memorials and monuments that paid homage to the huge human losses, honoured the heroes and hundreds of thousands of antifascists that fought in the war, commonly referred to as the Yugoslav Peoples' Liberation Struggle. ${ }^{236}$ The collective effort to commemorate the dead and celebrate the achieved freedom and progress based on proclaimed social and ethnic equality was aligned with the dominant political interests of the ruling Communist

236 During the four years of war in the Balkans, some 800,000 Yugoslavs joined the Peoples' Liberation Struggle; one of the highest proportions of participation in armed anti-fascist resistance in Europe. It ended with some of highest numbers of casualties, both military and civilian. Tony Judt, Postwar: A History of Europe Since 1945 (New York: The Penguin Press, 2005), 18
Party. The temporal and thematic scope of commemorated events often transcended the period of the Second World War, incorporating historical episodes that had previously remained uncommemorated, such as workers' struggles and peasant uprisings. The cult and memory of contemporary politicians, intellectuals and political movements, such as the geo-political position of Non-Alignment, was also mediated in public space through monuments and memorial parks. Artists and architects were heavily involved in the task of monument building, while their personal poetics, expressed through contemporary artistic means, became more and more encouraged, resulting in distinctive individual embodiments of collective traumas based on innovative and collaborative practices that aimed to surpass traditional disciplinary boundaries. These solutions were no longer simply expected to narrate the past events, but also to emphasize their progressive character through the use of contemporary artistic and architectural means.

The organization of public competitions for monuments began immediately after the war had ended, based in part on the standards and practices inherited from the interwar period. Some fundamental competition regulations had been established as the result of professional architects' asociations' continuous strive for more open and democratic procedures. ${ }^{237}$ Despite the different ideological framework, architectural competitions had already played an important role in the cultural exchange of knowledge and ideas on national level during the monarchic period. Although some projects were submitted by the architects who had gained experience and knowledge by living abroad, competitions primarily functioned as the connecting tissue of the

237 Bjažić Klarin, Arhitektonski i urbanistički natječaji.
Yugoslav cultural space, and as an important platform for experiment and innovation. Already at that time, as Grozdana Šišković claims, competitions had the potentia to spread new ideas and concepts within the pubic cultural sphere. In this way, ar chitectural projects not only influenced the trends within a single architectural scene, but their mediative role often proved to be the central facet of architectural competitions. ${ }^{238}$

In the first post-war decade, federal Yugoslav competitions for monuments rarely gave rise to satisfactory results. Conventional typologies and relatively conservative formal solutions prevailed until the early-to mid-1950s. But perhaps more importantly, the engagement of a wider public in critica discussions on this topic had not yet been achieved or even welcomed. The aim seem not to have been to foment experimentation and innovation, but to achieve the greatest possible efficiency and quality of production. For that reason, projects were often directly commissioned from highly skilled and experienced authors who had established themselves during in the in terwar period. They were now promoted to the position of masters who supervised and controlled production through a system of State Masters' Workshops (Državne majstorske radionice) for sculpture, painting and architecture, established in the immediate wake of the war in Belgrade, Zagreb and Ljubljana. Even when federal competition were organized, the ambitious proposals for monuments were often rejected or the decisions for casting or installing them would be postponed, as if juries were anticipating a different course of development of memo rial production in the following decade. ${ }^{23}$

238 Šišković, Architectural Competition Practice, 184

239 The competition documentation and information on federal competitions from the ideological concerns. The social request for memorials exponentially grew in the early 1950s, putting pressure on sculptors an architects to achieve a rapid and efficien production rhythm, which was manifested in standard typologies and repetitive motives, at times even recycled from the interwa period. With recognizable imprints of big architectural names, such as Jože Plečnik in Ljubljana, distinctive architectural schools were formed. However, due to the disciplinary division in workshops, architects involvement in monument-making was primarily manifested though collaborative assistance. The focus upon the formal qualities of central sculptural elements meant that projects would usually be credited to sculptors alone. For a change to occur, it was not only necessary to modernize the formal treatment of individual segments, but to come up with new collaborative methods that would enable a more comprehensive approach to the given task and the achievement of the so-much appraised modernist notion of the synthesis of all arts. In the wake of the political turmoil of 1948, more liberal understanding of cultural production in Yugoslavia diversified the field encouraging a new generation of visua artists and architects - well trained in the aforementioned workshops - to experiment with new formal solutions, looking for inspiration during state-sponsored scholarships in the Western European centres and in imported modern art and architecture exhibitions and magazines. Many sculptor and architects began to forge successfu early post-war period is rather scarce. Early Yugoslav competitions for monuments included: Monument to Marko Orešković in Korenica, Croatia (1946), Monument to the Liberators of Skopje, Macedonia (1946) Jajinci Memorial Park, near Belgrade (1947-1948), Memorial 0ssuary of the Fallen Partisans of Dalmatia (1948). 
III I I I

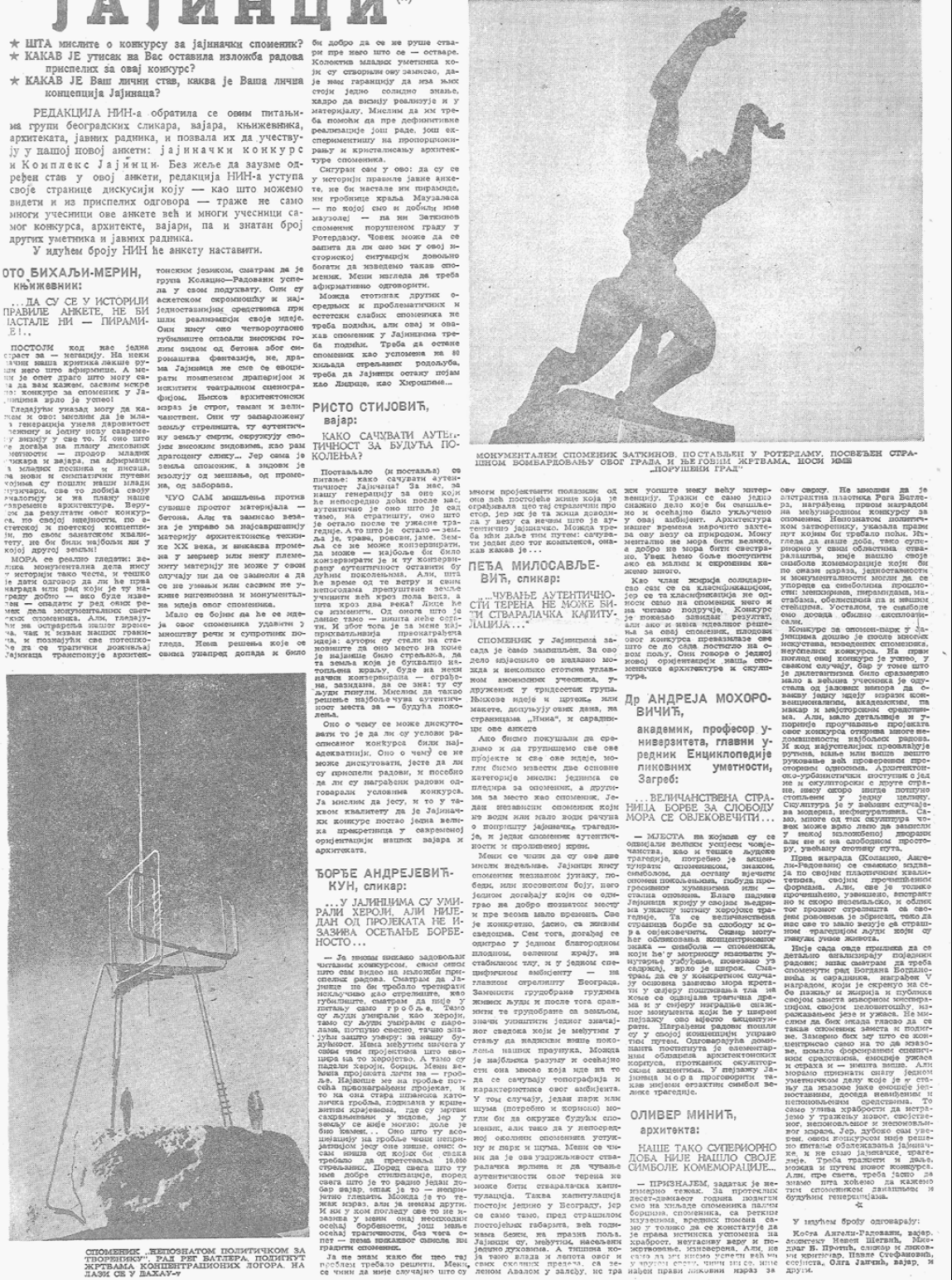

solo careers, and new public tasks - in cluding competition calls for monuments and memorial complexes - significantly influenced their studio practices, and encouraged them to undertake interdisciplinary collaborative work.

Despite sporadic examples of new concepts for monuments that had already been realized in the early 1950s - Edvard Ravnikar in Slovenia, Zdenko Kolacio in Croatia, or Bogdan Bogdanović in Serbia

- the scope of new tendencies in memoria sculpture became fully visible at federa competitions for monuments organized from the mid-1950s. Encouraged by Yugoslav participation at major international events such as the competition for the Monument to the Unknown Political Prisone held in 1952-1953, ${ }^{240}$ and by the critical reaction to the jury's rejection of Vojin Bakić's proposal for the for the Monument to Marx and Engels in Belgrade, ${ }^{241}$ the younger generation of artists and architects started to perceive competitions as an opportunity to

240 In a 1980 interview, Dušan Džamonja points to the importance of this international competition for his own work. Radmila Radojković, "Dušan Džamonja: Spomenik - izraz iskustva i povjerenja, Cetvrti Jul, 15 January 1980: 14

241 The reaction came shortly after the jury's rejection was made public. See: Milan Prelog, "Djelo Vojina Bakića," Pogledi, no. 11 (1953): 912-919., published as an English translation in: Ljiljana Kolešnik, ed., Hrvatska likovna kritika 50-ih - izabrani tekstovi (Croatian Art Criticism of the 1950s - Selected Essays)

(Zagreb: Društvo povjesničara umjetnosti Hrvatske, 1999), 453-469. For an analysis of the consequences this event had for art production and art criticism, see: Ljiljana Kolešnik: Između istoka i zapada. Hrvatska umjetnost i likovna kritika 50-ih godina (Zagreb: Institut za povijest umjetnosti, 2006), 312-316. nonymously present new ideas. ${ }^{242}$ Almos a rule, winning projects were extensively discussed and often harshly criticized in the media, tensions and polemics becam more common, references to Western European practices entered the field of critical discourse, and competitions began to play the central role in generating a new theoretical discourse on war memorials, as well as on public art and the production of space in general (III. 1).

However, change did not only come about as a result of the generational shift among the competitors; the investors and organ izing committees realized that no progress would be made unless competition propositions were adapted to the specificities of new tasks, and unless the field of memoria production - as with other fields of artis tic and architectural production - were to become more open and inviting toward contemporary art and ever more complex and innovative collaborative practices. Accordingly, competition juries grew in num ber and became more diversified in terms of their members' professional orientations. Due to its wide-reaching response from the younger generation, and the widespread critical echo it produced in the media, the competition for the Monument to the Victims of Fascism in Jajinci near Belgrade is particularly worthy of mention. The propositions for this open, anonymous Yugoslav competition seem to have established standards and remained one of the key referential points for decades to come. The Organizing Committee requested competitors to show the "full freedom (...) to think and develop the solution", by combining artistic, archi-

242 During the 1950 and 1960s, many sculptors and architects participated in major international competitions for monuments (Auschwitz, Dachau), with some of them achieving outstanding results (Dušan Džamonja and Ninoslav Kučan, Nandor Glid). 
tectural and landscape/horticultural elements, while paying special attention to the preservation of the authenticity of the former mass execution site. ${ }^{243}$ The competition attracted a total number of 34 competition entries, submitted by individuals and teams from various fields of practice. The projects rewarded by the jury, which was composed of 18 highly ranked politicians, intellectuals, and cultural workers from different parts of Yugoslavia, were innovative or even experimental solutions authored by dominantly younger generation of architects, urban planners and sculptors. The success and importance of this competition, both in terms of the quality of works submitted and in terms of the public and professional interest it provoked, becomes even more evident if we place it in the context of other competitions held in those years. The federal competition for the Monument to the Partisan-Fighter, held in 1956, which was also supposed to be built in Belgrade, did not bring any awarded projects, and, as Heike Karge concludes, its failure was the result of several factors, including the pretentiousness of the "old masters" who refrained from entering competitions. ${ }^{244}$ However, a more important reason was the newly established confidence of professionals who dared to oppose the incoherent propositions and the non-transparency of the organizing

243 Oto Bihalji-Merin, ed. Jajinci : povodom konkursa za idejni projekt spomenika žrtvama fašizma, Jajinci - Jugoslavija (Belgrade: Publicističko-izdavački zavod Jugoslavija, 1958.), 85-86. For more about the competition and the history of the memorial site, see: Sanja Horvatinčić "Povijest nemogućeg spomenika: izgradnja spomenika žrtvama fašizma u Jajincima," Anali Galerije Antuna Augustinčića, no. 32-33, 34-35 (2015): 261-282.

244 Heike Karge: Sećanje u kamenu okamenjeno sećanje (Belgrade: XX Vek, 2014): 107-115 body, namely, the special Committee for Marking and Arrangement of Historical Sites of the People's Liberation Revolution. It was in fact the first case of active opposition from a professional organization - the Union of Architects of Serbia - which argued for the necessary cooperation between professionals and politicians on such organizational tasks. Indeed, most of the plans that this specially formed, highly-ranked political Committee had for Yugoslav monuments failed, mainly due to their political exclusivity and unwillingness to keep up with expected democratic and open principles of public competitions. ${ }^{245}$ It confirms the thesis that monument-making in Yugoslavia, even when it came to tasks of utmost political importance, involved complex and dynamic processes based on negotiations and even open conflicts with the political establishment that, during the 1950s, still assumed it was able to fully control such practices.

However, many successful competitions for monuments, such as the one for Jajinci Memorial Park, did not result in the creation of monuments. The decisions would be postponed for different reasons, which are often today incredibly difficult to decipher. Another federal competition for the same memorial site was organized in 1980 , with a record number of jury members (35), attracting yet another generation of competing teams of artists and architects. Fervent discussions among some of the most renowned art critics, artists and architects, again filled up newspaper pages, with commentaries spanning from appraisal to harsh criticism, including complaints coming from the former camp inmates' organization. ${ }^{246}$

245 Ibid: 117-118.

246 "Da mrtav junak živima kazuje", Politika Ekspres, 1 February 1981, 6.; Bora Pavlović, "Još jednom oko rešenja spomen-parka u Jajincima", Borba, 26 Febraury 1981.
The final outcome was, however, the same: the winning project was set aside, and the monument, designed as the result of a direct commission from Serbian sculptor Vojin Stojić, was finally unveiled in 1988.

After three unsuccessful attempts, the 1980 competition for Jajinci Memorial Park was perceived as one of the symptoms of the "crisis of memorial production". ${ }^{247}$ This "crisis' determined the fate of many ambitious memorial projects completed in the early 1980s, such as the Monument to the Uprising of the People of Kordun and Banija at Petrova Gora, or the nearby "Brotherhood and Unity" memorial complex on Šamarica, both in Croatia. After being selected in a federal competition and constructed in the early 1980s, the latter soon faced the economic reality and the effects of the gradual collapse of the self-managed socialist system. This was manifested in the inability to maintain such memorial complexes, composed of monuments, hotels, museums, and other programs that needed constant management and continuous financial support. After the memorial house at Šamarica changed between several patrons, continually produced debt, and was unsuccessfully offered to all major hotel companies in Croatia, an offer by a private investor was accepted in $1988 .{ }^{248}$ This investor decided to take a risk and embark on a family 'memorial business'; an ambitious plan that was soon interrupted by the war and the collapse of the whole system, including the degradation of the symbolic references and ideological values these monuments and memorial site

247 Mirjana Živković, "Javna rasprava o konkursu za Jajince. Privid protivljenja". Politika, 17 December 1980.

248 The owner was Milorad Popović,

from the nearby town of Bosanski Novi

in Bosnia \& Herzegovina. Josip Frković,

“Memorijalac spašava privatnik," Večernji mbodied. Symptomatically, the "memoria crisis' that arose in the wake of growing economic and political problems in Yugoslavia seems to have been compensated by presentation of those same monuments at majo global art exhibitions, such as the Venice Biennale, where Yugoslavia was represented by major memorial projects from the 1960 s and 1970s.

BETWEEN DEMOCRATIC PRINCIPLES AND POWER POSITIONS

To an architect, a competition is not always about winning, but rather about the opportunity to engage in a high-profile discourse with other members of the design community. The open public competition is also an opportunity for young architects to make a name for themselves, to gain the recognition that is so essential to building a practice. (...) competition can also be a vital step in garnering stakeholder and public support for a project that may still be in need of funding and approvals in order to be realized. The competition, with its strong overtones of democratic process and meritocracy, carries widespread appeal from a civic point of view, and also give public officials many different creative solutions to the proposed design problem for very little upfront cost. ${ }^{249}$

Although all of the above could have applied to the prevailing attitude in the period and context investigated in this analysis, the views and attitudes on open competition were far from in unison. The pro and contra

249 Catherine Malmberg, ed, The Politics of Design: Competitions for Public

Projects (Princeton, NJ: Policy Research Institute for the Region, 2006), 3-4. 
arguments also depended on the structural positions from which those personally involved in the process spoke, as well as on their own material and professional interests. What is more, they depended on the positions of power within the field of artistic and architectural production. Some of the most renowned names of Yugoslav memorial production - each in their own generation - were keen to ignore or undermine the importance of democratic principles of competition and selection. Such attitudes often came from those among them - as the quantitative analysis will clearly show - whose structural position allowed them to skip tiresome and time-consuming competition procedures, and enjoy the privilege of direct commissions for monuments. This kind of structural imbalance produced undemocratic tendencies, cultural elitism, and the promotion of the idea of the "artistic genius". Paradigmatic examples of such attitudes were Antun Augustinčić and Bogdan Bogdanović. Although they belonged to different generations and fields of practice, their structural positions were in many ways comparable, which seems to have been reflected in their shared negative attitude towards open public competitions. On several occasions, Bogdanović expressed his scepticism regarding the functionality of public competitions, claiming they were good only for beginners and newcomers: "I think that competitions don't always give good results since usually, or even regularly, the mediocre projects win." ${ }^{250} \mathrm{He}$ confirmed that most of his memorial projects were commissioned directly, and expressed his belief that such tasks should be given to affirmed authors, because "when someone is given the trust and the credit, than it becomes not only an honour, but a

250 Vasa Kazimirović, "Bogdan Bogdanović Umijesto strave opredijelo sam se za život," Vjesnik, 3 July 1966 (hust be justified". Jouralists' questions regarding the rumours about the author being "backed by someone" were based on a controversy provoked by the lack of a regular competition procedure for the monument in Jasenovac. An pen competition for this monument was never held, although several authors were invited to submit their proposals. ${ }^{251}$ As Bogdanović himself claimed, only two projects entered the second round: his and the colaborative project by Zdenko Kolacio and Kosta Angeli Radovani. ${ }^{252}$ Such an unregulated and obscured procedure provoked many negative reactions from individuals and professional associations. After his first project for Jasenovac Memorial Area was publicly presented in Zagreb in 1963 (III. 2), the Croatian Architects' Association sent a letter of protest to the headquarters of the Federal Union of Veterans of the Peoples' Liberation War of Yugoslavia in Belgrade. ${ }^{253}$ By listing positive examples - public federal competitions for monuments in Jajinci near Belgrade and Kamenska in Croatia - they advocated for adherence to more democratic procedures when it came to the selection of the best projects for such important memorial sites. It was yet again proven that non-transparent commissioning procedures could not pass by without public reaction and complaint. In this case, however, the quality of Bogdanović's project and his professional renomé - despite criticism

251 See the chapter "Koncentracioni logor Jasenovac" [Jasenovac Concentration Camp] in: Heike Karge: Sećanje u kamenu okamenjeno sećanje (Belgrade: XX Vek, 2014): 193-244

252 Vasa Kazimirović, "Bogdan Bogdanović..." 253 Archives of Yugoslavia, Belgrade. Reg.: SUBNOR (297). File: 24 (Republički odbor SUBNOR Hrvatska 1949.-1971.): „Dopis Saveza arhitekata Hrvatske SUBNOR-u Jugoslavije“, March 19, 1964.
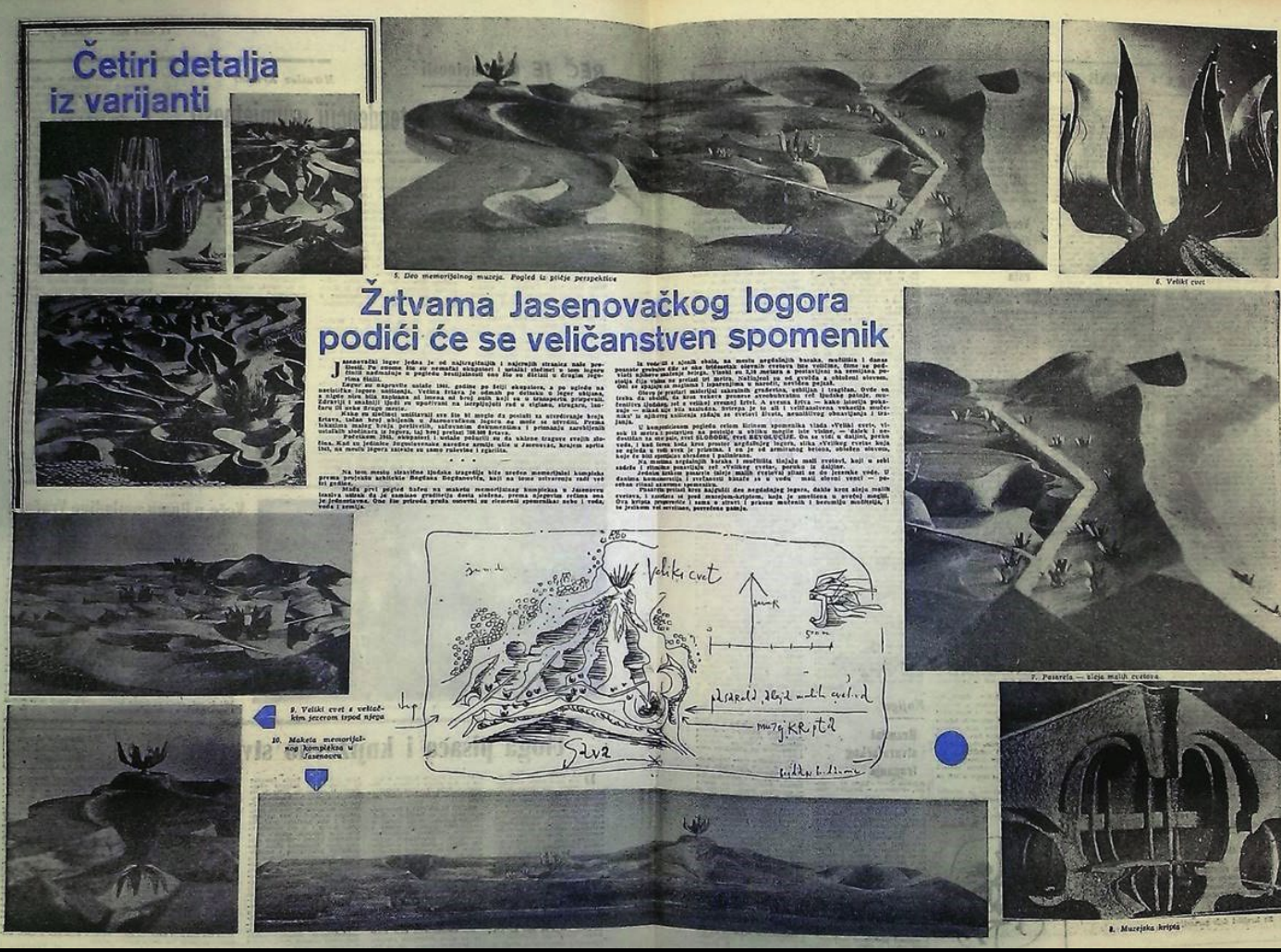

Zrtvama Jasenovačkog logora podici ce se veličanstven Spomenik podici ce se velicanstven spon

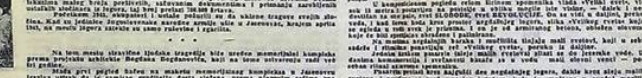
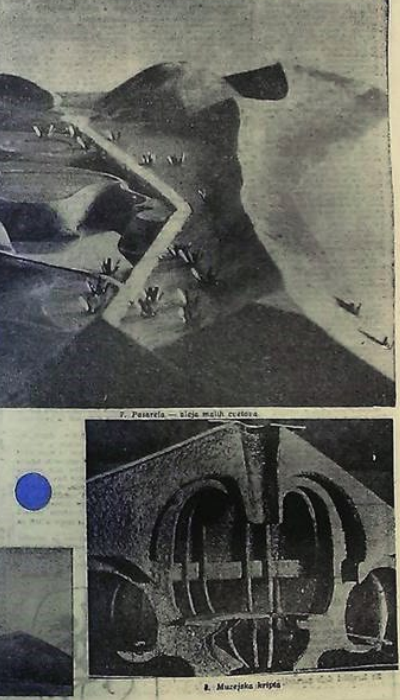

Bogdan Bogdanović's project for Jasenovac memorial com plex, presented on 19 March 1963 in Četvrti jul, the weekly magazine published by the Federal Union of Veterans of the Peoples' Liberation War of Yugoslavia. 
coming from some art historians and architects ${ }^{254}$ - seems to have established enough authority for the realization of the project. It is possible, however, that this affair expedited the process of the passing of the special legal regulation of monument building in Croatia in 1968, a law by which competitions for significant memorial events and people became obligatory, and by which juries were made to include professionals from the fields of art and architecture. ${ }^{255}$ The laws regulating this particular matter differed from republic to republic, which produced different standards and practices across Yugoslavia's various constituent republics. The same year, the Regulation on Competitions in the Field of Architecture and Urban Planning was also adopted. ${ }^{256}$ Although it was widely applied and called upon in the event of irregularities, the breaching of those rules had no legal consequences. This was likewise the case with the legal instruments that were aimed at protecting authorship. Affairs regarding Dušan Džamonja's winning project for the Sremski Front monument and Igor Toš's battle with the Committee for the construction of the monument at Petrova Gora - that will be discussed later in further detail - were perhaps the most notorious among these. Interestingly, Croatian sculptor Antun Au254 See, for example: Matko Meštrović, "Bogdanovićev projekt za spomenik u Jasenovcu (1963)." In Matko Meštrović. Od pojedinačnog općem (Zagreb: DAF, 2005), 127-128.

255 Zakon o podizanju spomenika historijskim događajima i ličnostima [Law on the Building of Monuments to Historical Events and People] Narodne novine. Službeni list Socijalističke republike Hrvatske, no. 1 (1968)

256 Pravilnik o konkursima iz oblasti arhitekture i urbanizma [Regulations on the Competitions in the Fields of Architecture and Urban Planning] (Belgrade: Savez arhitekata Jugosalvije, December 20, 1968) cause it is well known what Krleža can do, and how he writes, so if you commission something from him, you are expecting to get something in his style. (...) Finally, I know very well what competitions are. At best, they are an opportunity for the young and unknown authors; first and foremost, even if did compete, everyone would recognize me. What's the point of anonymity then? All sculptors with a certain physiognomy can be recognized. ${ }^{257}$

Both Augustinčić and Bogdanović criticized competitions from their respective, comfortable positions in the system, secured by their long-term involvement in the social network of competition procedures, either as competitors themselves - which for Augustinčic was already the case in the interwar period - or as prominent members of competition juries - as was the case with Bogdanović. The following analysis will, however, reveal some important differences in their structural positions which indicate to various strategies of attaining positions of power.

But after all, the regularity of a competition's procedure primarily depended on the com missioners and investors, whose decision it was as to whether a federal or lower level of competition should be organized and carried out according to the prescribed regulations. Despite the assumption that on the local levels, where competitions were not obligatory, direct commissions were more common, some examples show that it was not exclusively the professional and politica circles that guaranteed democratic pro cedures and highest aesthetic standards. On the contrary: since the decision-mak ers themselves were not particularly eage to adhere to or support such procedures,

257 Josip Škunca, "Antun Augustinčić:

Jedanput natječaj, drugi put ne", Vjesnik, 31 December 1970 ercen failed were perceived as corrupted. It was th direct stakeholders - local and politica communities, veterans, former inmates, and countless individuals who participated in the financing - who were mostly engaged and interested in the process of selection, but were rarely given the chance to participate in the decision-making processes. Some early examples - such as the Monument to the Husino Miner in Tuzla - show how citizens and workers were organized to discuss and collectively decide on the conceptual and formal aspects of monu ments. ${ }^{258}$ Decades later, an article about the competition for the Monument to the Liberators of Majdanpek in Serbia begins with the following statement: "Proof that competition for a monument can be carried out on the most democratic basis was shown by the citizens of Majdanpek and Donji Milanovac, who themselves voted for the proposals for monuments to revolution in those two towns." 259 The idea was to give everyone who donated money for the monument's construction the right to vote for project based on their own preferences. A competition was carried out in collaboration with the Applied Artists and Designers Association of Serbia (ULUPUDS). In late 1979, an exhibition of project proposals was organized, based on which the citizens of Majdanpek could select their favourites. The competition was not anonymous; al authors were present at the exhibition, and available to elaborate their ideas to the interested visitors. Slobodan Jovanović, a machine technician employed at the surface

258 Sanja Horvatinčić, "Monuments

Dedicated to Labor and the Labor Movement C'mon, tell Krleža, for example, to submit a novel for a competition. You wouldn't ask that of him. Instead, if you're interested, you'd commission a novel directly from him. Why? Be- 
mine at Majdanpek Minery stated that, "for the first time, as a citizen directly interested in a monument, I was put in the situation to vote for it. Since I am giving my own money, I don't feel indifferent as to what kind of monument is being built. I believe that every monument should be built in this way". ${ }^{260}$ The responsibility for the Yugoslav "memorial landscape" as we know it today, was, in fact, very much in hands of jury members and other decision-makers whose importance has not been adequately addressed so far. This may not be accidental: regulations, propositions, and political decisions are not exactly compatible with the modernist notion of autonomous, inspired artistic work, which is nowadays still associated with the prevailing notion of an "artistic genius". Much the same as the very notion of a monument - "burdened" with its necessary political function - competitions were a kind of blind spot of the high-modernist ideology.

\section{EXCEPTIONS, IRREGULARITIES, CORRUPTION}

To encourage, to spark, to fire up the creative potential of an architect, and to select the best among the best, this is the point of an architectural competition. The competition is the engine and the prioritizing mechanism that progresses the production of space. A tribune from which new thoughts are heard, a platform with a view into the future, a courtroom in which decisions are made according to, and despite, the laws, judged at the same time both objectively and subjectively. ${ }^{261}$

260 Ibid.

261 Milorad Macura, "Zapisi na marginama pravilnika o konkursima", Arhitektura Urbanizam, no. 16 (1962): 51. every other competitive system, Yuslav federal competitions for monuments were based on arbitrary decisions at the hands of jury members. Examples of direct-democratic decision making, as with the Majdanpek project, were but rare exceptions. Although a strong consensus prevailed that aesthetic decisions should be in the hands of professionals and experts, one of the persistent problems regarding the decision making was what Milorad Macura described as "evaluating new ideas by old criteria. Then conventional work gains over the progressive. And this obstructs the rhythm and degrades the level in the development of architecture and urbanism."262 The decision-makers were not, however, only professionals - juries were composed of diverse social actors, from highly ranked and local politicians, through representatives of war veterans, to public intellectuals and ordinary, low-skilled workers. It was the inner dynamics that decided on who would have the most influence in the final decision, and the "establishing of value criteria according to which juries selected and recommended architectural concepts was a complex field of dialogue between suggested architectural 'constructed realities', and the representative professional judgments". ${ }^{263}$

The power relationships were indeed often beneficial for professionals, since the majority of jury members belonged to that group, and cultural workers and intellectuals in general enjoyed a relatively high level of authority and prestige within society. However, in contrast to certain other forms of cultural production in socialism, where decision-making processes were more covert, it is almost impossible to claim that memorial production as such had any kind of autonomy.

262 Ibid

263 Šišković, Architectural Competition Practice, 184
Another issue was that of the different types of social relationships that existed among and between actors participating in the process, which necessarily function as obstacles to what would ideally be considered an objective evaluation. This was even openly confirmed by some prominent members of juries, such as university professor and art critic Grgo Gamulin who, in his polemic with Igor Toš over the competition for the monument at Petrova Gora in 1971, wrote:

The fact that all experts are "blocked by their positions and acquaintances' is a well-known and completely natural thing, and has as little as possible to do with you, whose works have not been known. (...) Do you really think I can't recognize com petition entries by Bakić, Džamonja, Luketić? However, it is the matte of the highest possible objectivity, of the wider pool of affinities and knowledge, and this is why the jury membership is crucial, and it has proven to be so in this case also. ${ }^{264}$

Although the full reconstruction of 'behind the scenes' scenarios is a demanding and largely unattainable task for historians, quantitative analyses can contribute at least vague outlines of the general physiognomy of the field. Federal competitions largely contributed to the professionalization of the field of memorial production which led to its gradual saturation. Perhaps most vivid critical view of the problem of specialization in the field of memoria production was given by Croatian sculptor Kosta Angeli Radovani:

264 Gamulin, Grgo. "Nesporazum o spomeniku. U povodu odgovora arh. Igora Toša." Hrvatsko Sveučilište, 13 October 1971.
I have always expressed my suspicion and lack of confidence toward the 'specialists'. One does not make a monument as they would make shoe or a pot. Each time, sculptura work brings different solutions, expressing different ideas. But thos who work in 'series' never make mistakes nor do they encounter difficulties like other sculptors do. Thei works are always fully completed a installed with the greatest pleasure. This is what enables the use of templates for repeating the same tested solution, and, as the author moves in the magic circle of the same idea and expression, his collaborators become all those who want to get an instant monument based on the same, certified sculptural expression. ${ }^{265}$

Anonymity was often difficult to achieve if we take into account the growing number of specialized authors who regularly sub mitted their proposals for monuments. Still, the system of coded entries encouraged participants to experiment more freely, or even enabled newcomers or 'underdogs' to overshadow the 'masters of the monuments'.

Competitions were usually organized through one stage. The second stage procedure would be introduced ad hoc, in case none of the awarded projects sufficed the requirements, a practice that does no comply with the generally accepted and prescribed professional rules for architectural competitions. ${ }^{260}$ The practice of 265 Radmila Radojmović, "Kosta Angeli Radovani: Izgubjeno poverenje u konkurse?" Četvrti Jul, 22 January 1980, 12.

266 In the regulated two-stage competition procedure, the first stage is meant for soliciting the ideas and the competitors 
organizing limited competitions by invitation was practiced throughout the observed period. One notable example is the closed competition for the monument celebrating the Battle of Sutjeska: the project by Miodrag Živković was selected by the jury as the best among the four competitors: himself, Stanko Mandić, Jovan Kratohvil and Boris Kobe. ${ }^{267}$ Since different models of competitions were never coordinated and regulated on the federal level, it gave way to manipulation of the procedure.

Perhaps the most controversial case was the competition for the aforementioned monument at Petrova Gora, Croatia. The competition was announced in 1970 as a standard single-stage, open, anonymous, federal competition. The names of the awarded projects - including the winning project by a young architect, Igor Toš, and collaborators - were publicly announced in press, and presented at an exhibition held in the Museum of the Revolution of the People of Croatia in Zagreb in July 1971. (III. 3) The jury gave their recommendation for the winning project to be realized. The idea of a second stage was introduced only a few years later, after the author of the winning project had already further developed and adjusted the project according to the re-

would remain anonymous, while the second would require more detailed plans for the final selection. Compare, for example, the regulation set by the International Union of Architects. Guidelines UIA. Competition Guide for Design Competitions in Architecture and Related Fields. Accessed January 3rd 2019. https://www.uia-archi tectes.org/webApi/uploads/ressourcefile/32/ uiacompetitionguide.pdf

267 The jury consisted of the following members: Vlado Madarić, Uroš Martinović Bogdan Bogdanović, Branko Bon, Živa Dorđević, Milorad Panić Surep and Dragi Milenković. "Ocena konkursnih radova", Miodrag Živković Archives, Belgrade, 1964. quirements of the investor. His solution had y then already been publicly announced; the project in the making was even supplemented by a visual identity based on Toš's design, reproduced in the papers and official communication channels of the committee board. ${ }^{268}$ The construction of the monument according to Igor Toš's project and the physical plan by Ante Marinović-Uzelac, was supposed to begin in 1975 , and be finished by July 1976, on the 35 th anniversary of the uprising of the people of Croatia. ${ }^{269}$ The decision to carry out the second stage of the competition, which came about after a new Committee for the Building of the Monument was constituted in $1973,{ }^{270}$ provoked an open letter from the author, who decided to speak out regarding rregularities in the procedure and copyright infringement issues. ${ }^{271}$ This sparked an official reply from the Committee, ${ }^{272}$ after

268 A similar example of "branding" memorial projects before the construction even started can be found for the monument at the Syrmian Front near Šid. An icon of Džamonja's winning project at the competition was even drawn on a map of monuments published along with the a guide to Yugoslav monuments in 0sijek in 1975. See: Milenko Patković, and Dušan Plećaš (eds.), Spomen-obilježja narodnooslobodilačkog rata Jugoslavije. Vodič uz kartu. Izbor spomen-obilježja narodnooslobodilačkog rata Jugoslavije (Osijek: Glas Slavonije, 1975).

269 M.B., "Spomenik na Petrovoj gori 1976.", Vjesnik, 23 November 1973

270 "Konstitutiran dbor za gradnju spomenika na PEtrovoj gori", Vjesnik, 18 March 1973. As the president of the Executive committee was appointed Rade Bulat, and as the secretary Mile Dakić. 271 Igor Toš, "Natječaj - samovolja ili društveni dogovor?", Vjesnik, 16 March 1975. 272 Sekretarijat Izvršnog odbora - Odbora za izgradnju spomenika na Petrovoj gori, which the author protested once again. ${ }^{273}$ The controversy over this case has never been fully resolved, and the role of Igor Tos soon went into oblivion. The project itself however, did not - Toš's project seems to have served as an inspiration for Bakić's second proposal. The similarity is especially noticeable if Bakić's second project is observed in opposition to his first idea for the monument (III. 3). Besides the copyright issue, the second stage of this competition seems to have been problematic in some other aspects as well. Stevan Luketić - who was invited to participate in the second stage of the competition - wrote a lette of protest in which he refused the decision of the jury because, among other things, "it did not evaluate all three projects equally", and allowed some participants to correct, change or supplement their project according to jury members' suggestion and objection after the deadline. ${ }^{274}$ Furthermore, although it was an uncommon practice, the jury decided to postpone of the deadline on the request of Vojin Bakic due to the health problem of his son and collaborator at the project. ${ }^{275}$ The final de

“Tko gura privatni interes", Vjesnik, 23 March 1975

273 Igor Toš, "Pokušaj prebacivanja odgovorinosti", Vjesnik, 3 April 1975.

274 The undated, hand-written draft of the letter is kept in Stevan Luketić's personal archives. It is not clear whether the letter was ever sent and delivered to the Committee for the Building of the Monument to which it was addressed.

275 The document, dated 24 January 1975 , by the Committee for the Building of the Memorial-Object at Petrova Gora, signed by Rade Bulat, the director of the Executive Board, and delivered to: Vojin Bakić, Stevo Luketić, Ivo Vitić, 16 members of the jury, and to the Headquarters of the Memorial Park Petrova Gora in Vojnić.

$140 \quad 141 \quad$ Stevan Luketić Archives, Zagreb. de only in 1977 - this time not (he Committee for the Building of the Monument. ${ }^{276}$ As Gamulin claimed, the "signature" of established authorities in the field of memorial production did not only became easily recognizable, but their initial inspiration and their experimental approach in time often resulted with the same sort of repetitive solutions, so strongly criticized regarding Socialist Realist monuments in the early 1950s by the very same authors. In some cases, the same project would be successfully submitted to several competition calls. ${ }^{277}$

The professionalization of the field and the crisis of the institution of open anonymous competition became most eviden in the 1980s, when the practice of limited competitions (or competitions by invitation) became more common. It seems to have better suited both the investor, who avoided complex procedures and put les money at risk, and the invited authors, who were financially compensated regardless of the competition outcome. After the republic competition for Dotrščina, organized in $1977,{ }^{278}$ did not bring about a satisfy

276 "Rad V. Bakića najprihvatljiviji", Vjesnik, 29 June 1977.

277 The winning project for the monument in Čačak was later rejected due to the fact that the authors applied the same proposal to several competitions: Nikola J. Baković, "Konačan odabir idejnog rešenja za projekat Spomen-parka u Čačku, Izvornik. Građa međuopštinskog istorijskog arhiva Čačak, no. 33 (2017): 316 . Some of Džamonja's entries - for example, his his winning project for the Syrmian front and the project proposal for Donja Gradina were only slightly adapted to new task. 278 After a group of authors (Vojin Bakić Josip Seissel, Silvana Seissel, Angela Rokvić) were given a direct commission in the late 1950s for the first phase of the 
I NAGRADA AUTOR: IGOR TOŠ, dipl, inž, arh. SURADNIK:

TUMUR CEVEGDJAV, stud. arh MAKETA:

IVICA SUSOVIC, stud. stroi

FOTOGRAFIJA:

FOTOGRAFIA:
PETAR KELEMINCIC

RASVJETA:

ZORAN ŠONC, dipl. inž. el.

TROŠKOVNIK:
MARKO KUCINAC, grad. teh.

TEHIIICKA SURADNJA:

BORISLAV DOKLESTIC, dipl. inž.
arh.

svi iz Zagreba
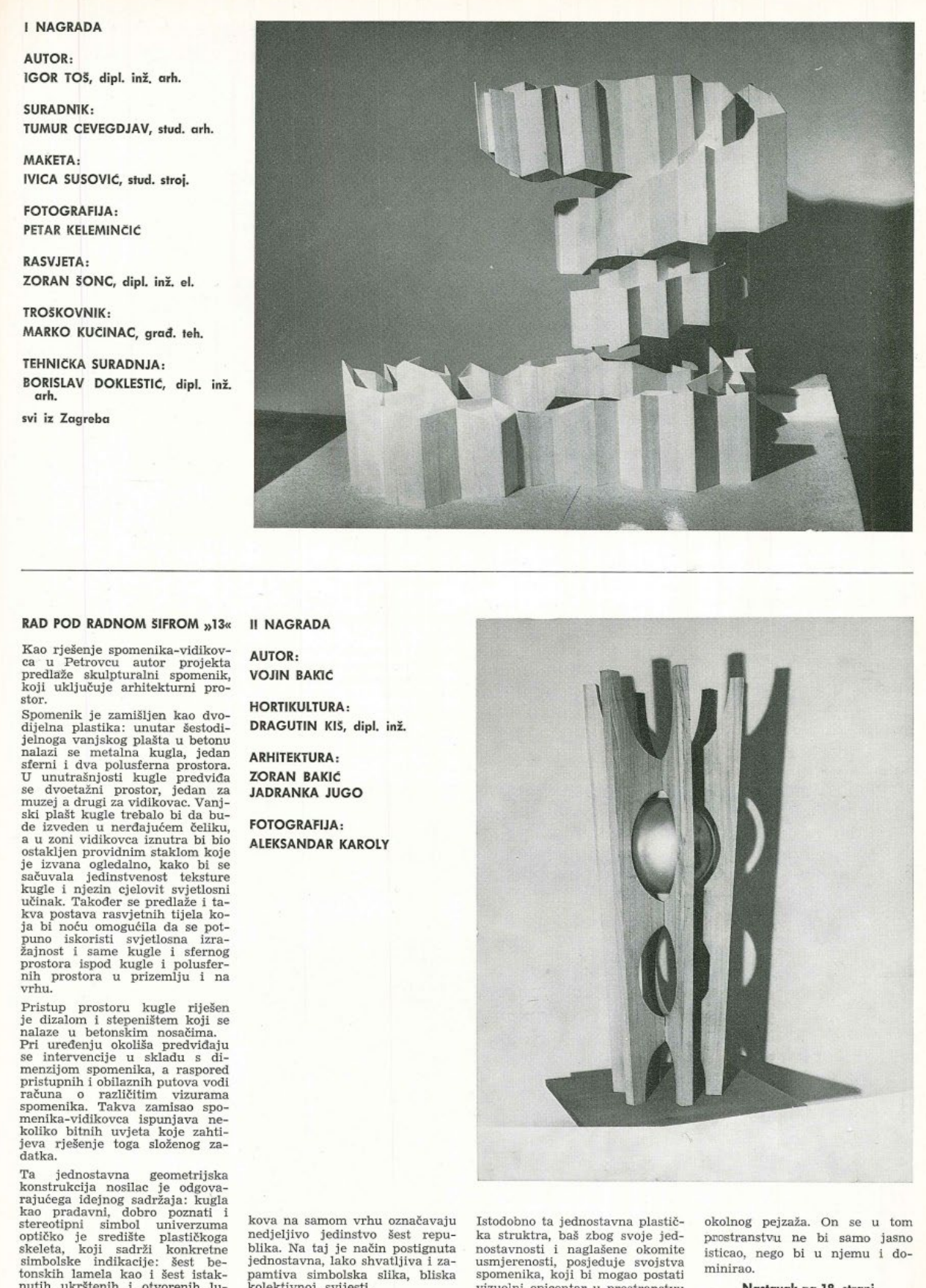

II NAGRADA

AUTOR:
VOJN BAKIC

HORTIKUITURA:

DRAGUTIN KIS, dipl, inž

ARHITEKTURA:

ZORAN BAAIC
JADRANKA JUGO

FOTOGRAFIJA:

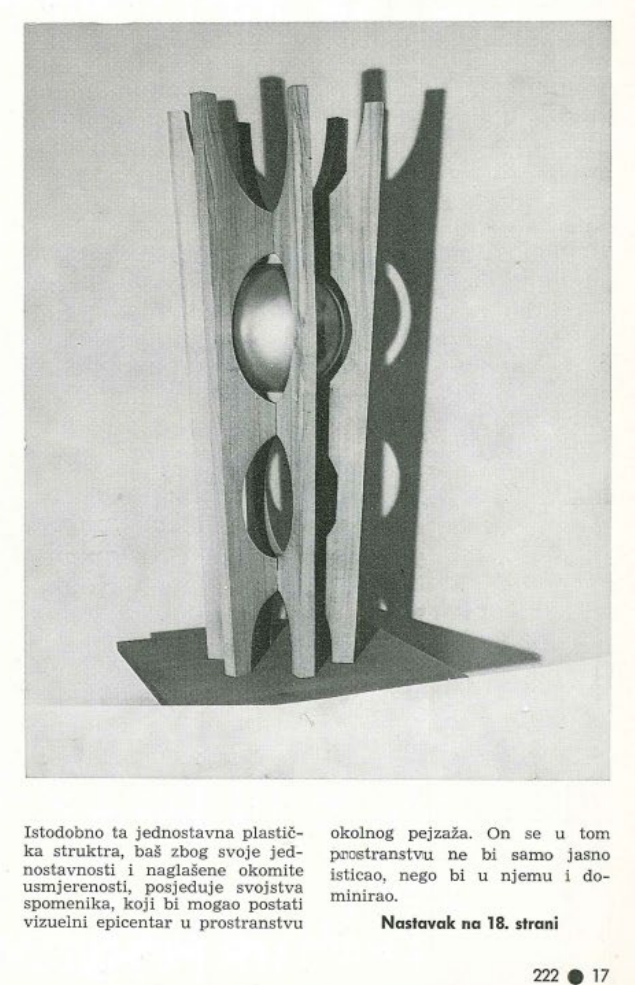

III. 3 ing result, the jury suggested organizing another, limited, competition with invited authors, "who have so far achieved most significant results in the design of memorial parks/areas." ${ }^{279}$ The authors selected for the next closed competition, a federal one for the Monument to Tito and Zadar's Fight for Freedom in Zadar (1983), were almost identical. ${ }^{280}$ The results were unsatisfying as the authors' ideas were, contrary to the intention of the invited competition, already exhausted. ${ }^{281}$ They offered predictable, standard solutions, while the younger generation of artists - who were critical or cynical of what they perceived as a privi-

279 The following nine authors were invited: Kosta Angeli Radovani, Vojin Bakić, Zlatko Čular, Dušan Džamonja, Mladen Galić, Ljerka Šibenik, Zdenko Kolacio, Stevan Luketić and Branko Ružić. Each of them was required to submit one design for the central monument, one by their choice, and one alternative solution for another monument (the planned monuments had to cover nine thematic subjects). For the design of the entrance square and the memorial museum, the following architects were invited: Mirko Bičanić, Nevenka Postružnik, Boris Krstulović, Neven Šegvić and Ante Vulin. Ibid.

280 The following authors were invited: Kosta Angeli Radovani, Vojin Bakić, Dušan Džamonja, Zdenko Kolacio, Branko Ružić and Šime Vulas from Croatia, and Miodrag Živković and Bogdan Bogdanović from Serbia. Antonija Mlikota, "Natječaj za spomenik drugu Titu i vjekovnoj borbi Zadra za slobodu iz 1982. godine," Anali Galerije Antuna Augustinčića, no. 32-33; 34-35, 2015., 302

281 I.0., "Pomanjkanje etičkog i profesionalnog odnosa", Vjesnik, 8 Janaury, 1983; Vjekoslav Pavlaković, "Slojevit a nedefiniran proctor", Vjesnik, 8 January 1983; S. Ab., "Natječaj za spomenik Titu i revoluciji. Sedam neuspjelih radova", $143 \quad$ Vjesnik, 12 December 1982 leged field of propaganda art practice was professionally discouraged, and even personally unmotivated to participate in such projects. This also came about as one of the symptoms of memory politics crisis that resulted from the political crisis in the country during the 1970s, and especially in the 1980s. The economic situation (inflation economic 'stabilization' campaigns, cuts in public financing, etc.), meant less money for costly and often unsuccessful competition procedures, including awards and jury honorariums. All illusions and ideals seem to have vanished, and pragmatism took over: the insistence on the principles of democracy of selection with open, anonymous, federal competitions again - as in the early post-war period - became secondary to the preferred efficiency of the procedure and the quality of the results. The golden age of experimentation was over.

\section{QUANTITATIVE AND NETWORK ANALYSIS}

After defining the general framework, of fering a glimpse into the practical aspect and issues of competition procedures, with an emphasis on various issues associated with practical implementation of such democratic selection procedures, the second part of the text will focus on the figure derived from a quantitate analysis of all case studies included in the study. Although still relatively new and epistemologically amorphous filed, Digital Humanities provides researchers with new tools, and encourages the extension of analytical scope to the macro-level, thus broadening our perspective beyond an isolated set of historical episodes. The advancement in digital technology make such endeavours more realizable, offering ever-more complex algorithms for describing and visualizing historical phenomena, and also facilitated the recreation of dynamic interrelations among people, objects and 
events. ${ }^{282}$ This does not imply confinement or reduction to a positivist approach; on the contrary, digital tools enable research in the humanities to complement, supplement, amplify or correct the results of standard historiographical methods. Although simple data analyses have always been employed as technical tools for practically-oriented niches of art history, the recent development of computational technology has enabled the processing of bigger datasets, integrated into complex relational information systems. Network analysis has navigated the discipline toward social processes and their effects, thus imposing the necessity of inter- and trans-disciplinarity. As most theoreticians and practitioners argue, these new analytical techniques can affect the evolution and undamental approaches of art history, or even radically transform its epistemological, theoretical, and interpretive scope. ${ }^{283}$ The degree of 'radicalism', however, depends on the wider cultural and epistemological context in which digital tools are to 'meet' traditional approaches. The most important value of quantitative analysis employed in the current study is, as Benjamin Zweig claims,

[...] that they can problematize the weighty claims put forth by scholars based upon very small data sets. By displacing the centrality of exceptional works of art or individual biographies into larger networks, this approach can function as a research

282 Among the growing number of titles on the topic, see, for example: Susan Schreibman, Ray Siemens, and John Unsworth, A New Companion to Digital Humanities (John Wiley \& Sons, 2016).

283 Nuria Rodríguez Ortega, "Digital Art History: An Examination of Conscience," Visual Resources: An International Journal of Documentation, vol. 29, no. 1-2 (2013), method that raises new questions about historical events and as a potential mode of historiographic critique. As the foundation for methods such as topic modelling and data mining, the quantitative analysis of art historical data can be both a challenge and a complement to the case-study model of practice. ${ }^{284}$

Yugoslav federal competitions, functioning as important intersections of various social actors and creative hubs from which new experimental approaches to the memorial genre emerged, do not only offer an insightful methodological angle for the critical historical analysis of memorial production, but can also critically inform art-historical periodization. As such, competitions present a suitable case study for the analysis of a specific, task-oriented, multi-professional social network, based on the idea that the two main entities in the system - competitions as networking events and people with different roles (participant or jury member) - can be (inter)connected in various ways.

\section{METHODOLOGICAL PARAMETERS} AND LIMITATIONS

The timeframe of this case study (1955-1980) has been elaborated in the previous section: In the mid-1950s, federal competitions for monuments began functioning as platforms for experimentation of a younger generation of artists and architects, and competitions' outcomes started to induce fervent critical discussions in the media. The beginning of the 1980s, on the other hand, marked the gradual decline of memorial production,

284 See: Benjamin Zweig, "Forgotten Genealogies: Brief Reflections on the History of Digital Art History," Digital Art History Journal, no. 1 (2015): 45-46. with this 'crisis' reaching its peak in the second half of the last Yugoslav decade. As, under current circumstances, it would have been highly demanding, if not impossible to collect data for all federal competition held in the defined period, a representative sample consisting of 24 case studies has been formed. Three of these competition lack full documentation regarding participants. ${ }^{285}$ However, the decision to include them in the representative sample is intentional and methodologically motivated, as it demonstrates the extent to which a shortage of information - as a common and unavoidable issue for most social and humanist re searchers - can affect the overall datascape and visualization of networks. Although this dataset can be expanded through further research, our estimate is that the given sample suffices for the outlining of some genera features, and indicates certain conclusions about the social structure and networking models generated by the federal Yugosla competitions for monuments during the 25 year period studied.

In order to analyse this specific, task-oriented, multi-professional social network, we will look at quantitative data and interrela tions between two types of network entities: events (competitions) and people (awarded competitors and members of juries). The data processing and analysis was done with the use of the CAN_IS database developed through the ARTNET project, ${ }^{286}$ while some

285 There is no information on the jury members for the Memorial Park "Brotherhood and Unity" at Šamarica. The Memorial Park of the Women's Movement in Skopje and Memorial at Korčanica in Bosnia \& Herzegovina, on the other hand, lack information about awarded projects.

286 The results of the project are published in this volume, while the framework, methodology, and some preliminary results have already been presented in: Život umjetnosti (thematic issue: Digita with other open source programs (Tablea and Gephi). After all available data was collected from a combination of published and archival sources, it was inserted in the predefined categories, quantified, and/ or visualized as networks though specially developed algorithms in which the position, size and colour of nodes and edge reflect a particular relational, categorical or quantitative attribute. My initial hypothesis was that the results could offer some new insights into the phenomenon or that some of its hidden aspects would be highlighted, and that such results would open up new research questions.

\section{QUANTITATIVE ANALYSIS \#I:} COMPETITIONS

All competitions taken into consideration in this analysis were open, anonymous and conducted at the federal level, meaning that they were open to all citizens of $\mathrm{Yu}$ goslavia, while the entries were coded and evaluated by specially appointed panels of judges. The names of jury members had to be made public, as well as the author and team members of awarded and purchased works were in most cases publicly announced. For most competitions, it was also possible to reconstruct the total num ber of submitted proposals by using primary sources in the archives, or newspape reports and interviews with jury members. The diagram in Fig. 1 is organized as a timeline featuring competitions organized in th period between 1955 and 1980. The size of squares translates as the number of submitted entries. The highest density of competitions is evident in the period 1965-197 (marked with a yellow square), when a tota number of ten competitions were launched

Art History, Ljiljana Kolešnik ed.), no. 96 (2016) 
in six years. In just two years (1969-1970), six competitions were held, with a total number of 232 projects for monuments competing (denoted by an orange square). It should be noted that these figures are far from complete, which offers us a sense of proportion in terms of numbers of actors engaged in the production of monuments and memorial complexes in socialist Yugoslavia. They are equally telling regarding the effects of the aforementioned process of professionalization and saturation of memorial production. In is interesting to note that some competitions were even held simultaneously: those for the Monument to the Peasants' Uprising in Donja Stubica and for the Monument to the Victims of Fascism in Podhum (both held in 1969-1970 in Croatia), or the competitions for the Monument at Mt Kozara, Bosnia and Herzegovina, and that in Kraljevo, Serbia (both held in 1970). Two side effects of such overlapping can be detected: On the one hand, the lower number and lesser quality of submitted works produced dissatisfaction from organizers and jury members, and competitions often failed or were postponed. On the other, however, it dissolved the concentration of 'big names', giving more space to the 'outsiders'. In the previously discussed competition for the Monument to the Uprising of the People of Kordun and Banija, both of these side effects were manifested: due to the high popularity and historical significance of the events that took place at Petrova Gora, the total number of 17 entries was considered to be relatively low, while the triumph of the 27-year old architect Igor Toš's innovative solution definitely came as a big surprise. The outcome of the competition for the monument in Donja Stubica was similar: a number of sculptors belonging to the middle generation won high prizes, among them one female sculptor (Marija Ujević-Galetović). Due to the complex circumstances previously discussed, in both awards did not guarantee the of winning projects.

Although, due to the incomplete list of competitions included in the analysis, their spatial distribution (Map 1) cannot bring any definite conclusions in terms of the geo-spatial policy of monument making in Yugoslavia, it is noticeable that a considerable number of competitions were organized for monuments in urban centres, which were mostly dedicated to individuals or meant to represent abstract ideas (Edvard Kardelj and Revolution in Ljubljana, Vladimir Nazor in Zagreb, Marx \& Engels, Moša Pijade and the Park of Friendship in Belgrade, etc.). On the other hand, the competitions for the most important war memorial sites - located in uninhabited rural areas where historical events took place - attracted more interest and creative energy from the artists and architects, as is visible from the numbers of submitted proposals.

QUANTITATIVE ANALYSIS \#II:

AWARDED PARTICIPANTS

The geo-spatial distribution of the cities and towns from which awarded competitors submitted their proposals, their number indicated by the size of the circles, shows that the production was concentrated in the three big cultural centres of Yugoslavia: Belgrade, Zagreb and Ljubljana (Map 2). The disproportion between the number of projects submitted from the capitals of Slovenia and Bosnia \& Herzegovina, for example, confirms the importance of strong architectural and sculptural traditions asociated with established art and architectural schools. This further indicates the difference in general artistic and architecural production standards, but it may also suggest the significance of the ability to esablish professional and personal connections with decision makers which was more

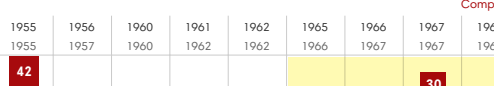

20

30

34

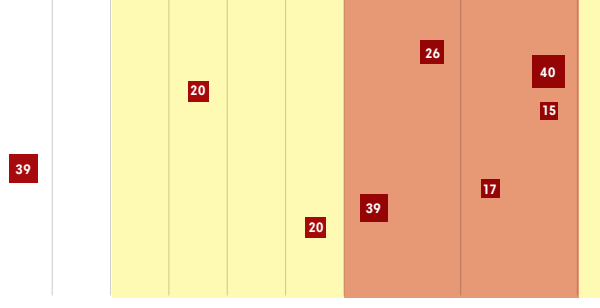

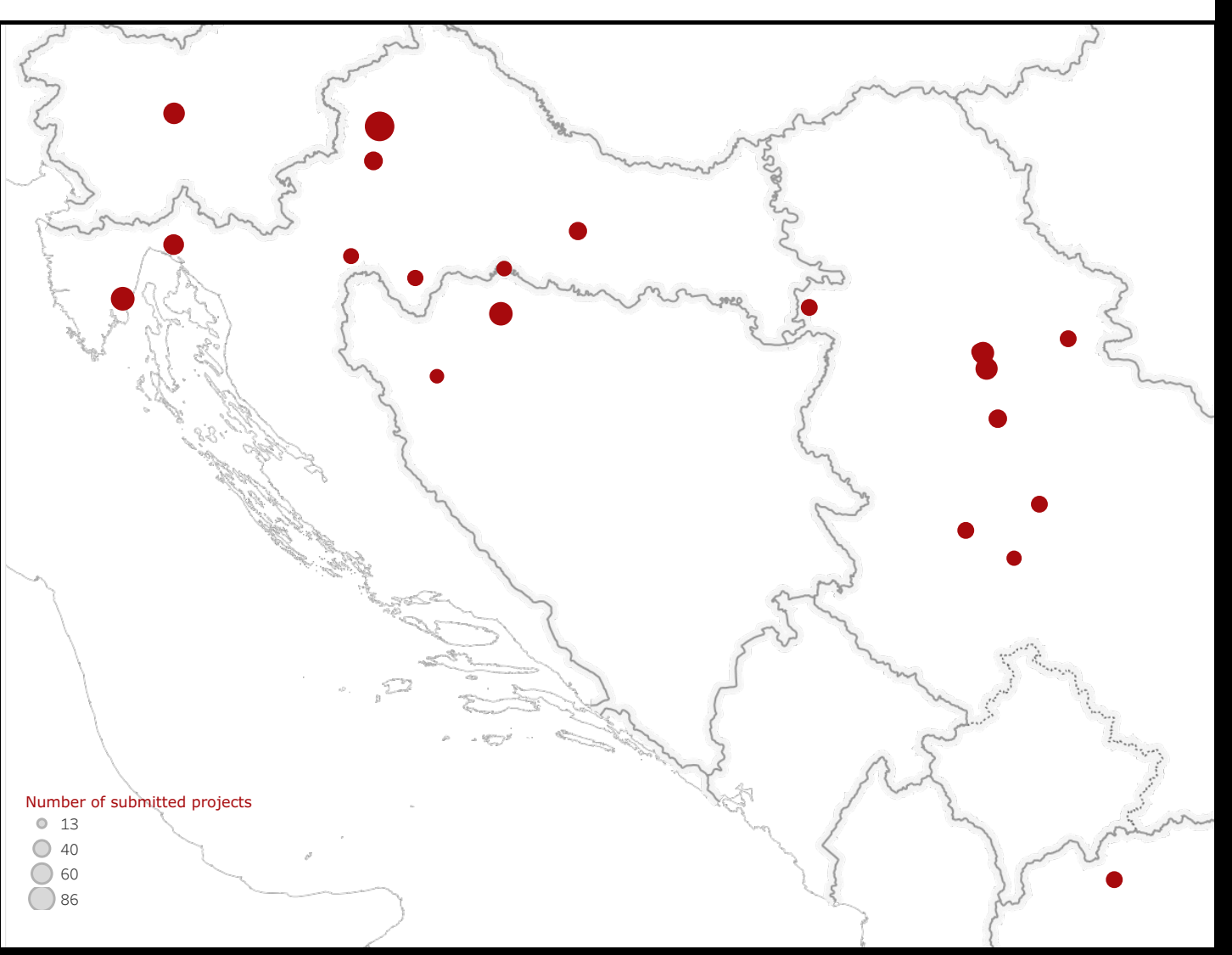

Fig. 1

A timeline of all competitions organized in the period between 1955 and 1980

Map 1 
likely in bigger political and cultural centres. On the other hand, the number of authors from other republics' or provinces' capitals (Skopje, Novi Sad, Priština), or towns such as Maribor, Subotica, Čačak or Rovinj, proves that the efforts of cultural decentralization since the mid-1950 did have a certain degree of impact on the quality of production in the peripheral contexts. Although it was difficult to visualize the inter-republic flow of works, the data presented confirms that federal competition continually played an important role in bringing projects from different parts of Yugoslavia to one table, thus contributing to the trans-republic (today international) exchange of ideas. It should be noted, however, that teams mainly consisted of practitioners from the same city/ town, although there are several cases of networking among team members from different republics.

Another interesting result of the quantitative analysis is related to the gender of awarded participants. Since this study is primarily concerned with social networks of all participants, and not with their individual roles in project designs, calculations were performed for all contributors in competing teams. ${ }^{287}$ Out of a total of 397 names featured in the publicly announced awards and purchases, 322 were male and 75 female. This means that about $19 \%$ of awarded contributors at federal competitions were women, mostly architects. This is somewhat surprising if we take into account the overall low percentage of women credited as authors of this type of memorials. As the analysis for monuments in Croatia has shown, only about $3 \%$ of sculptors and $10 \%$ of ar-

287 The distinction between authors and collaborators on a particular project was not made for the purpose of this analysis, although it is indicated in the database itself. chitects were women. ${ }^{288}$ This brings us to the conclusion that public competitions, which usually required bigger teams and often involved collaborative practice, allowed more women to enter the field. However, while this reveals that female contribution was greater than expected, their contribution - i.e. female artistic/architectural labour - often remained invisible, as they would mostly participate in bigger project teams, with projects usually credited to men. Since most of the awarded competitors were architects by profession, the fact that women in Yugoslavia were often specialized in landscape architecture - a profession that itself was undervalued - also contributed to their higher percentage in this field of production. While this may lead us to the conclusion that public anonymous competitions were beneficial for female authors, in reality their contribution usually remained unrecorded or ignored. These figures do not only confirm the general notion of the gender bias in the fields of fine arts and architecture, but help us to attribute their causes to the structural limitations of the whole system.

Besides offering a general view on the types of professionals engaged in high-level memorial production in Yugoslavia, the quantitative analysis of the professional orientation of awarded participants gives rise to several other important conclusions (Fig. 2). Of the total number of 378 participants whose profession could be identified, $77 \%$ were related to architecture, spatial planning and engineering (architects, urban planners, landscape architects, engineers, architectural technicians or students of architecture). Surprisingly, only around $12 \%$ were sculptors, or around $18 \%$ were from all fine art professions, including professions such as painters and graphic designers.

288 Horvatinčić, "Spomenici iz razdoblja socijalizma u Hrvatskoj," 118-119.

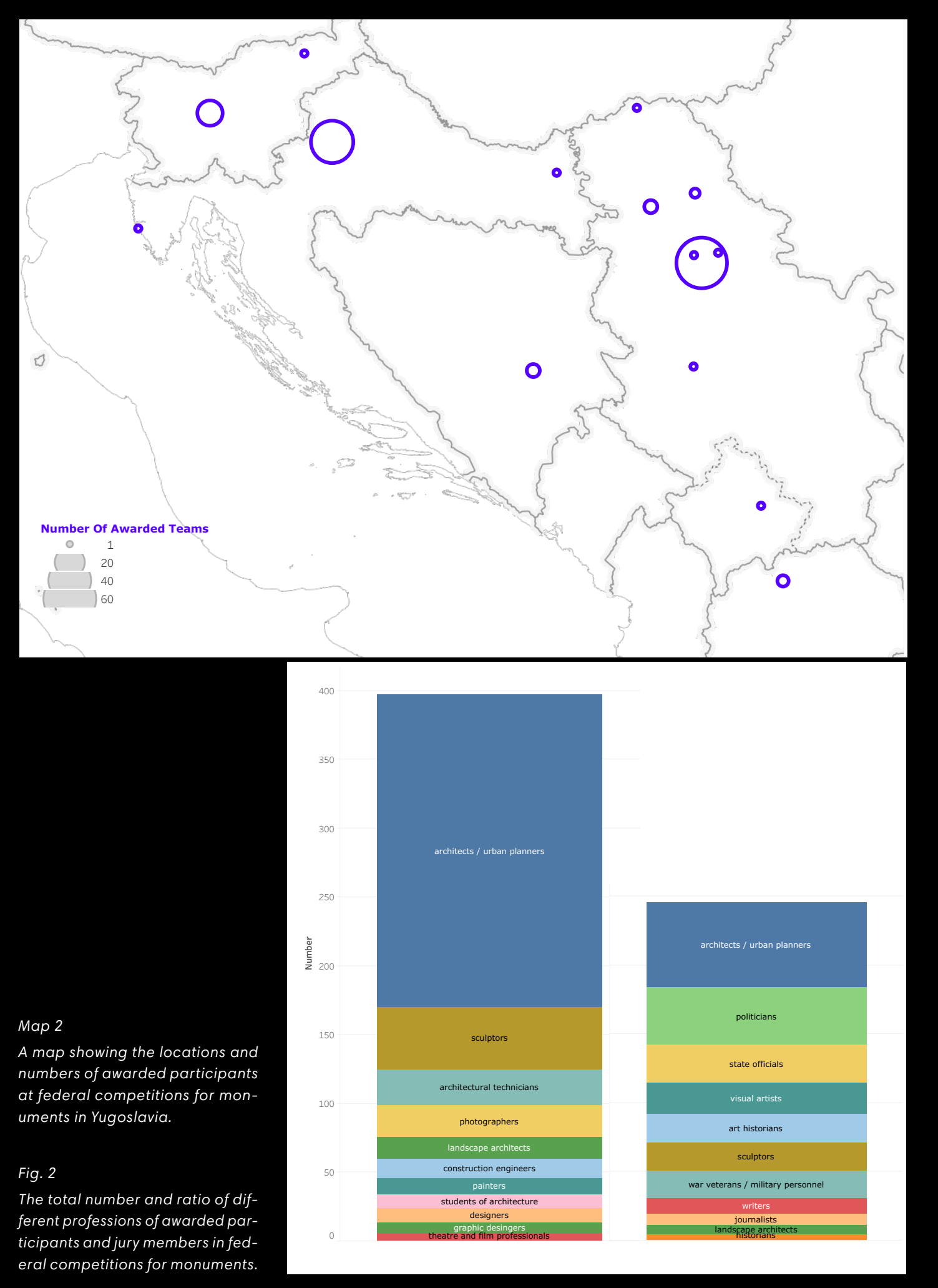


These figures would be somewhat different were we to look only at the signed authors of projects. Project documentation for more complex competition tasks, i.e. those that included urban planning, architectural drawings, and various presentational materials (photographs, models), demanded bigger and more heterogeneous working groups, often including architectural studio employees or trainees. This analysis shows that the highest level of memorial production in Yugoslavia was dominated by architects, whose pronounced interest in spatial relations and social functionality contributed to the typological innovations. This was already observed by art historian Matko Meštrović who, in 1961, after seeing the exhibition of the winning projects for the Monument to the Victory of the Peoples' Revolution in Kamenska, Croatia, wrote:

A very important positive fact is that architects are more frequently answering to the task of designing and constructing monuments. This derives from a more open, far-sighted, free and daring approach to monuments; from the will to widen its radius, and the inner dimension of its temporal-spatial existence, being and radiance; from the ever more realistic anticipation of its concrete sense and lasting purpose. A monument is no more a head, a gesture, a figure; more and more often, a monument becomes a designed space which penetrates life in a more realistic way. This last competition can show us how far we have gone on that path. If we are not satisfied with its results, we can be satisfied with this. ${ }^{289}$

289 Matko Meštrović, "Idejni projekti za spomenik u Kamenskom (1961)". In Matko Meštrović. Od pojedinačnog opće $\overline{\text { (Zagreb }}$
After discussing Branko Ružić's and Vladimir anović's innovative project for a monument-school, he finished his inspired, optimistic report with the hopeful projection: "Indeed, soon we may be building schools at the place of future monuments." 290 While Meštrović's prophecy did indeed come true, and functional monuments became more frequent in the following decades - be it as educational centres or touristic facilities it was not merely because the architects answered the calls in greater numbers, but because the competition propositions required technical and urban planning skills. At the same time, they encouraged more integrative approaches that required experimentation, cross-disciplinary collaboration and innovation.

\section{QUANTITATIVE ANALYSIS \#III:} JURY MEMBERSHIP

Seen from this perspective, the statistical analysis of the jury members' professional occupations appears even more imporant (Fig. 2). About $60 \%$ of the total of 239 jury members were architecture $(25 \%)$ or fine arts (18\%) professionals, art historians, theoreticians and conservators (8\%), or writers, journalists and other public intellectuals (8\%). The politics-related jury members comprised approximately $37 \%$ in total: $17 \%$ were active political figures, while the remainder were war veterans and state officials (ambassadors, military personnel, etc.). Some jury members had multiple professional prerogatives, being - like Koča Popović, who presided the jury for the first competition for Jajinci - at the same time politicians, war veterans, poets, ambassadors and public intellectuals. The statistics show that the majority of decision making in the field of memorial production was

\section{DAF, 2005), 124.}

290 Ibid, 125 controlled by cultural workers, predominantly by professionals active in the sphere of architecture, urban planning, fine arts, higher education and theory. The disparity between architects and artists is somewhat surprising, if not counter-intuitive: there are about three times fewer sculptors in jurie than architects and urban planners. Land scape architects were relatively well represented, given their marginal role in the in terwar period. After the competition for the memorial park in Sarajevo was announced in 1966, landscape architect Smiljan Klaić from Zagreb wrote a protest note in the prestigious Zagreb-based architectural journal Čovjek i prostor, provoked by the fact that none of the 13 members of the jury were landscape architects or sculptors:

The results of the competitions have so far shown that those solutions in which a harmonious composition of the park with buildings and sculp tures were the most successful. (...) We are deeply surprised by the fact that the "city of parks" announce a competition for a memorial park that will not be evaluated by any of our landscape specialists because none are sitting upon the jury. (...) We think that the problem of sculpture and its placement in the greenery is another specific issue, for the evaluation of which the selection of a sculptor as one of the jury member would be more appropriate than a painter. To conclude, it would be in the best interest of the quality and correct assessment of the competition entries, for which the city of Sarajevo will give 5 million dinars, to extend the existing jury to include the aforementioned specialist for landscape architecture and sculpture. ${ }^{29}$ into account the competition turned out o be unsuccessful, as none of the project were awarded the first prize. ${ }^{292}$

The overall predominance of the more technical, pragmatic and problem-solving disciplines, such as those of architect and urban planners, is a logical yet rarely affirmed and analysed notion in the existing literature on monuments. This has, on the one hand, produced interdisciplinar collaboration, but it also explains the tensions that were present between architects and sculptors, who felt threatened by architecturally pragmatic approaches and often more effective results. Whil some sculptors continued the old mode of using architects as technical support keeping a clear distance between the respective contributions of both authors, others - usually the younger, post-wa generation - successfully advanced their own practice through fruitful collaboration with architects, urban planners and landscape architects, adopting the gained experience and knowledge, and using it to their own advantage - opening the ways towards new concepts and typologies. A third group, however, developed an antagonism towards architects, claiming that

many such architects allow themselves to go on adventures more than to something we could cal successful explorations (...) trying to get beyond their bureaucratic cliché manners, through which the paraphrase and repeat some solutions that had originated in othe

sko-pjezažno-skulpturalno rješenje spomenpark u Sarajevu," Čovjek i prostor, no. 148 (July 1958): 5.

292 N.n., "Rezultati konkursa za spomen park na Vracima", ARH: Časopis društva arhitekata Sarajevo, no. 9, vol. 3 (1966): 5-32. 
social, ideological, and even financial-economic possibilities and relations. ${ }^{293}$

\section{TOWARDS A NETWORK ANALYSIS}

The lists of the twenty most awarded and most connected authors, and most frequent and most connected jury members (Fig. 3) gives an adequate transition to the network analysis. Its main purpose is not only to show the interconnections within the network, thus revealing the structural positions of individual actors, but also to indicate their various and multiple roles in relation to competitions, enabling us to visualize the complexity of this type of task-oriented, multi-professional social network.

From the gender perspective, it is interesting to notice that among twenty most awarded authors there were four women, while no women were equally highly ranked within juries. On the other hand, the structural position of the Serbian female sculptor Olga Jevrić is mainly determined by a relatively high degree of centrality. Some of the most famous authors of monuments were not eager to run for competitions, but their degree of centrality is nevertheless high due to their common participation in the decision-making processes, which not only confirmed their high social status in Yugoslav society, but secured them constant and diverse contacts with various social agents, from politicians to important professionals attending jury meetings from all over Yugoslavia. The most striking example is Bogdan Bogdanović, whose frequent role in juries secured him the highest degree of centrality in the jury network. Similar can be said of Edvard Ravnikar, Ivan Sabolić, Josip Seissel, Zdenko Kolacio,

293 Stevan Stanić, "Posle konkursa: Bez priča i potpričica," Nin, January 25, 1981: 68. more frequently as jury members than as competitors. Some experienced architects and urban planners, for instance Fedor Wenzler, successfully balanced the two roles and 'sat on two chairs'.

Bogdanović's presence in decision-making processes becomes even more apparent if connectedness with other jury members is observed (Fig. 4), or when his connections are highlighted within the whole network visualization (Fig. 5; coloured purple). When compared to the connections established by other actors with the highest number of awards or purchased works (Dušan Džamonja; coloured blue), and those of the person with the highest number of connections with other awarded participants (Aleksandar Krstić; coloured green), the extent to which Bogdanović was structurally embedded within the network is striking.

Before the further discussion, which, based on these results, will focus on the analysis of the structural positions of two statistically dominant and (art) historically important figures - Dušan Džamonja and Bogdan Bogdanović - we shall give a brief synopsis of the general features of the network.

GENERAL FEATURES OF FEDERAL COMPETITIONS' NETWORKS

In this analysis, we looked at two types of actors: awarded participants and the members of the panel of judges. In both cases, we are dealing with a limited number of people that form bipartite networks; either through participation in the same group of architects/artists whose project was awarded at the competition, or through sharing membership of the same panel of judges. The visualizations were generated from the predefined datasets inserted into the relational database. Depending on the parameters used and algorithms employed,
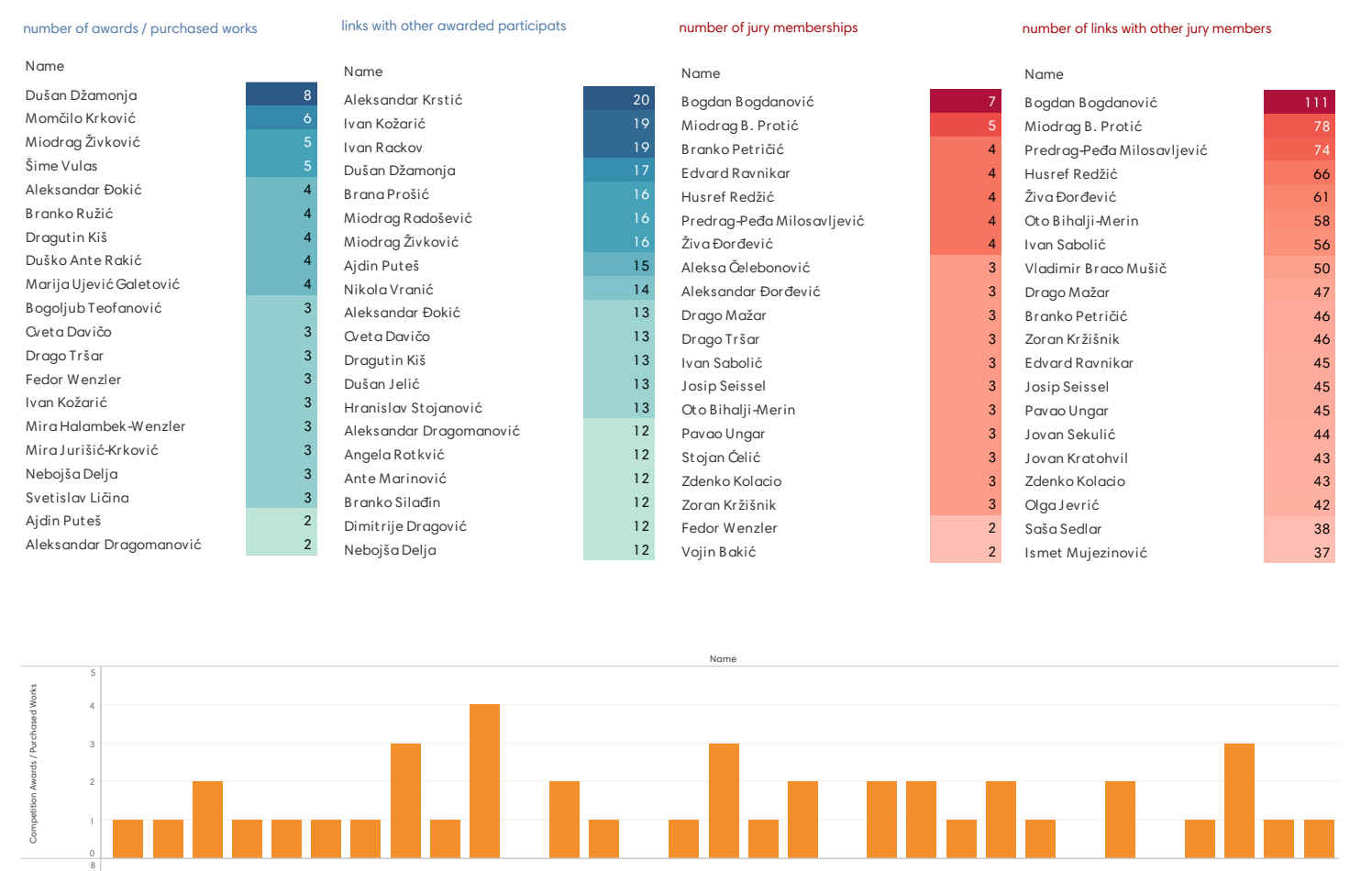
(untul

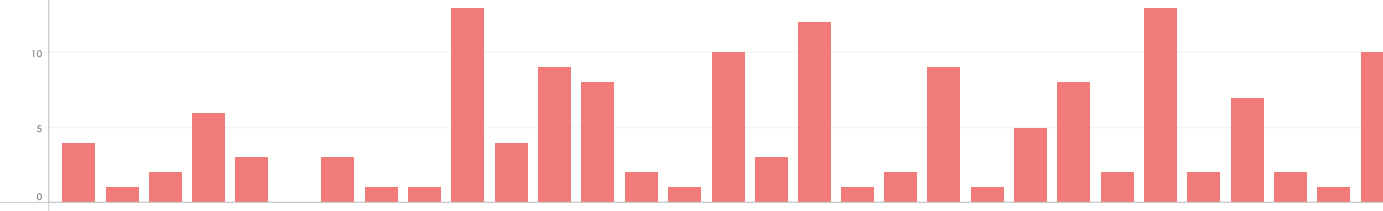
${ }_{80}^{100}$

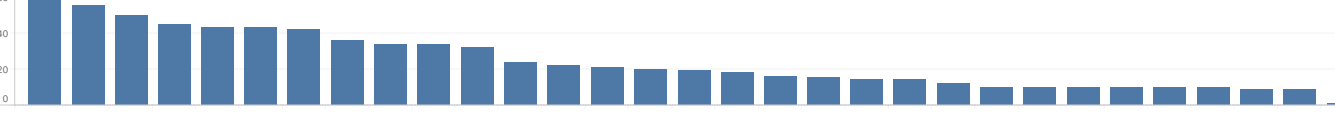
Fig. 3 Ranking lists of the twenty most-awarded and most-connected competitors and jury members. Fig. 4 


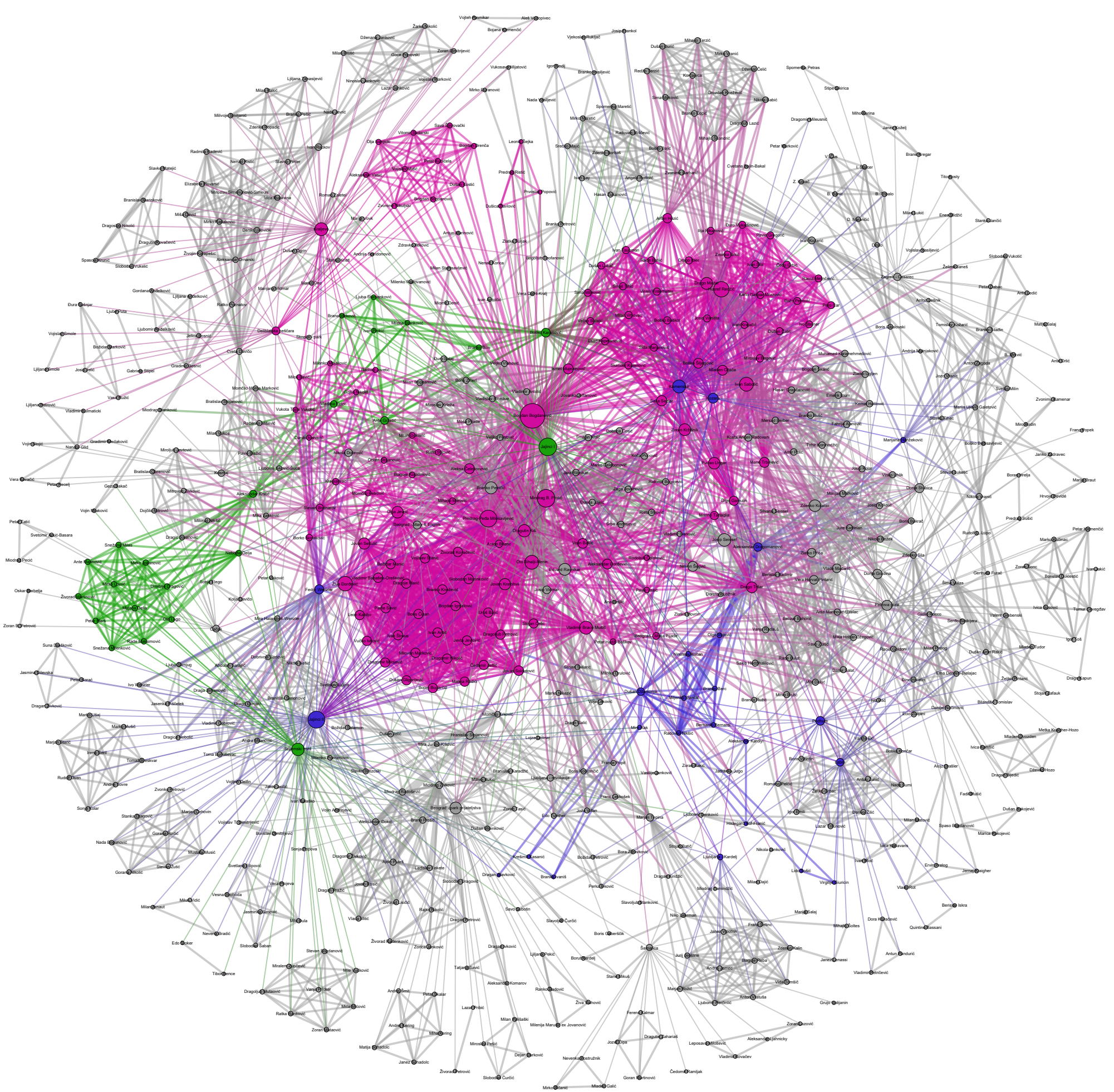

The complete network with highlighted connections of Bogdan Bogdanović (purple) Dušan Džamonja (blue) and Aleksandar Krstić (green).; Generated with Gephi we are able to generate different visualizations. Networks can significantly differ as a result of whether we decide to limit the data to awarded participants, their mutua relationships and their relationships with competitions (Fig. 6a), or if only jury members, their mutual connections and the connections with competitions are shown (Fig. 6b). From these visualizations it is clea that in both scenarios all competitions are well connected, most of them having multiple relations with other competitions, both through joint jury memberships and through the fact that the same authors were award ed. The network of participants, shown in Fig. 6a, has a wider diameter and is les dense, which indicates less cohesivenes among network members. The participants' network, due to the nurturing of collaborative and team work, is at the same time characterized by a larger number of smaller, isolated groups of project teams. On the other hand, the network of jury members is denser, yet it features two groups which are conspicuously isolated. Those groups of jury members are linked to the competitions for monuments to Edvard Kardelj (Ljubljana Slovenia), and to the Victims of Podhum (Croatia). The reason for this may be that the organizers chose more local actors, possibly also with the intention of attracting more local contributors. It is interesting that the 'gatekeeper' for the Kardelj monumen was Slovenian architect Marjan Tepina, who was also a jury member for the monument to the Revolution in Ljubljana, while the gatekeeper for the Podhum competition was Grgo Gamulin, who, around the same time, also evaluated the works in the competition for the Kozara monument, and who wrote extensively and self-reflectively on both of these decision-making experiences. However, for the purpose of generating the whole complex network featuring both datasets, a different software (Gephi) was used, because it offers more sophisticated 

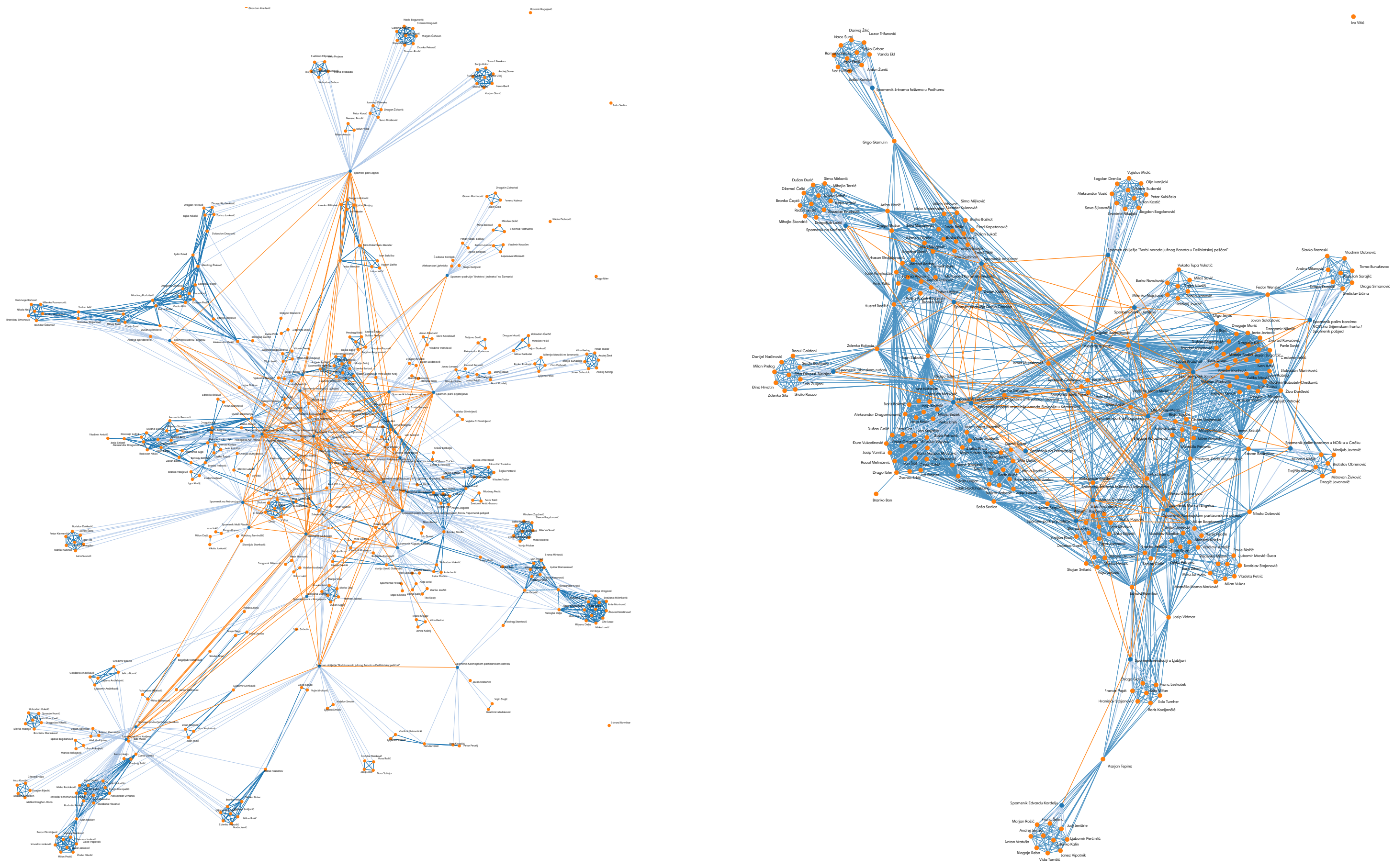

and thus become more easily detectable (Fig. 7). In this network, both groups of entities (competitors and jury members) are brought together. Different types of edges are distinguished by different coloured lines (pink - joint work on a competition entry; green - joint jury membership; light blue - participation in a competition as a jury member; yellow - participation in a competition as a participant), while the size of the two types of nodes (architectural competitions and people) are ranked in size based on the degree of centrality. The nodes could not be differentiated by colour because many actors, as we have already shown, played dual roles throughout the period. A comprehensive reading of this visualization therefore requires decent knowledge of the profiles of the most prominent actors. The network itself is characterized by a high density in the central part, where the green type of edges - joint jury membership - is dominant. A series of smaller groups of teams working on joint competition entries are located along the network periphery, indicating a low degree of centrality of those actors. The degree of centrality of blue nodes signifying competitions is especially interesting. As expected, the first competition for the Jajinci memorial is located at the very centre of the visualization, thus statistically confirming the emphasized importance of this event in terms of establishing standards and anticipating the future trends in federal competitions. The centrality of the node indicates that the very same authors - for many of whom this competition was the first chance to become noticed and be rewarded for their innovative approaches - continued to be active within the field of memorial production in the following decades, either as competitors or jury members. Similar can be said of other larger

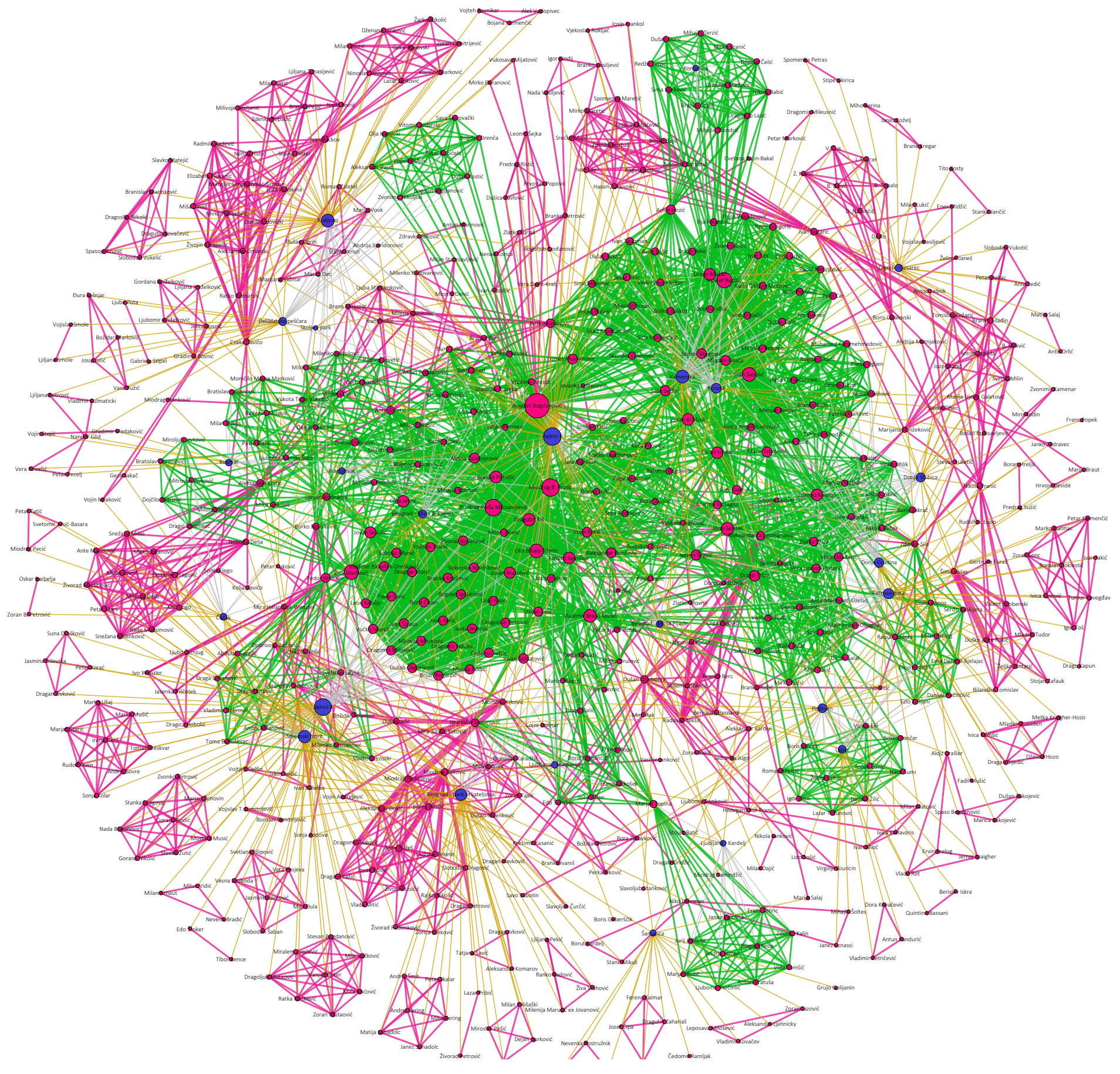

Fig. 7

The network showing all entities included in the relational database of 24 federal competitions for monuments (1955-1980). Generated with Gephi. 


\section{CENTRAL FIGURES IN THE}

NETWORK - THE CASE OF

BOGDANOVIĆ AND DŽAMONJA

The second most central or dominant node in the visualization shown in Fig. 7 is Bogdan Bogdanović. Although Dušan Džamonja, due to the small number of collaborations and lack of jury participations, is characterized by a relatively low degree of betweenness centrality, he was the most prominent participant, taking part in the largest number of competitions. We compared the backgrounds and structural power positions of these two statistically prominent actors. It is, however, well known that both were highly prolific authors in the field of memorial sculpture and architecture, retaining leading positions within the system throughout the period studied. How was it then possible that their structural positions in the network visualization were not more balanced? The answer lies in the fact that they employed different strategies for establishing and maintaining their power positions.

Dušan Džamonja (1928-2009) and Bogdan Bogdanović (1922-2010) belonged to the same generation. They both experienced the Second World War: the young Bogdanović participated in it actively on the Partisan side, while Džamonja was a highly receptive witness to the horrors that surrounded him as a child. The creative work of both artists was deeply affected - or even determined - by their wartime experiences. Despite the fact they had different backgrounds - one trained as an architect and the other as a sculptor - both manifested a strong desire to cross the boundaries of their medium. This not only resulted in major differences in their poetic language, but early on brought

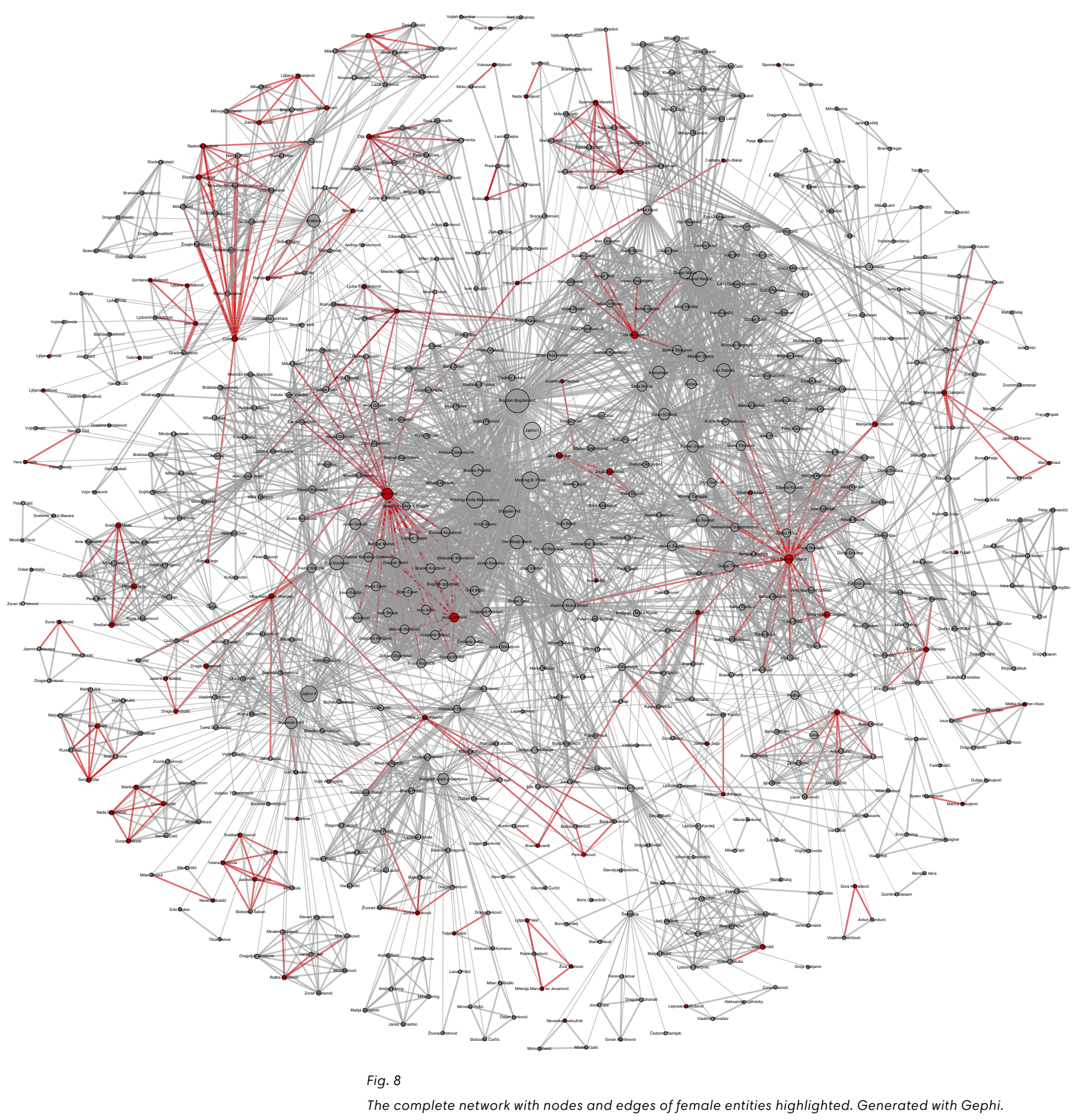


them both to the field of memorial sculpture that allowed for such kinds of experimentation. Although they had already been recognized among most talented authors in the first half of the 1950s, the competition for Jajinci memorial (1957) was a landmark event for both of them, and the only occasion in which they both participated as competitors. They established themselves professionally in early 1950s, both as outstanding, leading artists and architects of their generation. At this point, however, their careers took different paths: Bogdanović became a member of the Faculty of Architecture in Belgrade in 1953, thus beginning his life-long academic career that was crowned by the title of Professor Emeritus in 1987. His institutional power grew even stronger when he took on leading roles in professional organizations, such as the Yugoslav Union of Architects (1964), and when he became a member of the Serbian Academy of Sciences and Arts (1970, resigning in 1981). Džamonja, on the other hand, took the path of what today would be classified as a freelance artist. Interestingly, he managed to do so in a socialist system in which there was no real art market. In part, presumably, this may have been possible precisely due to the system of public competitions in which he would regularly participate. After gaining enough experience, skills and confidence at the Academy of Fine Arts in Zagreb and at Frano Kršinić's Master Workshop (1951-1953), he almost completely broke away from the existing hierarchical structures and practices of the art academy, and embarked on an independent career. Besides developing a successful international career, applying for numerous public competitions was his main strategy for developing experimental practice in open-space large formats, and maintaining an independent position within the Yugoslav art system.

Despite different structural positions and strategies, Bogdanović and Džamonja were

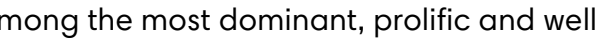
established names in the field of memorial production in former Yugoslavia. The geographic reach of their monuments was among the widest, but the commissions were obtained in different ways. While Džamona continued to enter public competitions throughout his career, Bogdanović abandoned this practice very early on, instead continuing to work through direct commissions. This is also clearly visible from their positions within two respective networks: that of the participants of the winning projects - where Bogdanović takes the central position - and the network of the jury members, in which - surrounded by politicians, war veterans, public intellectuals and several other prominent architects and sculptors - Bogdanović looms as the central figure. His connectedness to the jury members at different competitions, and his continuous presence in decision-making processes, his social esteem as a public intellectual, critic and theoretician - all of these were crucial for obtaining direct access to commissions, thus bypassing the tiresome and often risky process of running for competitions. Zdenko Kolacio's structural position and strategy was rather similar - although being one of the most prolific architects in this field of practice in Croatia, he also soon gave up on submitting project entries, and became a highly prominent figure within juries.

The main difference between these two strategies of securing position within the system of memorial production depended on the material conditions. Džamonja as a freelance sculptor chose to earn his living by making art, and was thus forced to use every opportunity to acquire funding and honoraria. The dynamics of such working conditions allowed him to spend more time in his atelier, preparing the extensive and detailed project documentation. On the other hand, figures such as Bogdanović and Kolacio, who enjoyed great renown in society and were permanently employed at universities or urban planning offices, were invited directly. Their position was therefore privileged compared to those authors usually emancipated freelance sculptors - who were highly dependent on the system of competitions. This also explains the ways in which Bogdanović's structural position conditioned him to speak against public competitions. We must keep in mind that his deep involvement in the decision-making processes made him highly aware of all corruptive, unregulated and problematic segments of that system.

\section{STRUCTURAL POSITION OF} WOMEN IN THE NETWORK

In addition to conclusions drawn on the basis of gender-related statistics, the visualization presented in Fig. 8 is even more telling in term of female positioning within the whole system of federal public competitions for monuments in Yugoslavia. The red nodes and edges represent the positions and con nections of all female actors within the net work. It is clearly evident that the majority are located along the peripheral edges of the visualization, where women often composed the majority of project teams. As the statistics have shown, women were pres ent in the field of memorial production to a greater extent than would be expected, but since they usually worked as collaborator upon projects that rarely won first prizes, they were neither professionally nor financially motivated to stay in the field of memoria production or encouraged to compete with their own proposals. Women with a highe degree centrality were often spouses of more successful and famous architects and sculp tors, with whom they worked in teams, like Mira Wenzler-Halambek, wife of Fedor Wenzler, and Mira Jurišić Krković, wife of highly prolific Serbian sculptor Momčilo Krković. fursional limitations derived from uch artistic partnerships should be further investigated, but they certainly contributed to the structural obstacles women had to endure in their professional careers. On the other hand, the high degree of centrality of the sculptor Olga Jančić and Vera Horvat Pintarić, prove that it was not impossible for women to become part of the decision-making cliques. Despite the bette social position of women in socialism, it was, however, much more difficult for women to meet the criteria and come to such positions: both Jančić and Horvat Pintarić, each in her own field of work, were completely devoted to their careers, achieved the highest professional standards, and were internationally renowned and connected.

\section{CONCLUSIONS}

Digital Art History allows researchers to use new digital tools in order to include more actors, voices and (hi)stories in an analysis that has so far been constrained and limited by selective approaches and biased perspectives, dictated by the grand narra tive schemes of the Western world. Although the main objectives of digital art history are usually described in terms of quantitative, socio-cultural, spatial analysis, with a tendency toward transnational and transdisciplinary inclusion of all actors included in the creative process, ${ }^{294}$ this study has shown that the same methods can be equally beneficial to the analysis of smaller-scale and localized phenomena. What is more, it has shown that, for phenomena such as public competitions, it is necessary to take into account not only those actors who crea-

294 Béatrice Joyeux-Prunel, "ARTL@S: A Spatial and Trans-national Art History Origins and Positions of a Research Program," Artl@s Bulletin, Vol. 1, No. (2012): Article 1. 
tively participated in the process, but to juxtapose and overlap their collaborative networks with those networks generated in the decision-making sphere. As the first part of the analysis - based on qualitative approach or standard historiographical methods - has shown, jury members were not only crucial for making decisions; their structural position in the system of high-level memorial production significantly influenced the dynamics and division of power positions, constantly challenging - or even threatening - the democratic principles of public competitions. Without paying attention to jury membership, it would not have been possible to detect the division of power positions among certain prominent authors, as we have shown in the examples of Bogdan Bogdanović and Dušan Džamonja. Competitions for monuments nevertheless managed to maintain a relatively high degree of interest and competitiveness throughout the observed period. Although participation at federal competitions was limited exclusively to Yugoslav citizens, from today's point of view these competitions can be considered as transnational networking vehicles. It is also important to emphasize the importance of quantitative logic in social network analysis to opposing the methodological nationalism ${ }^{295}$ still present in most local art historical studies. Federal competitions were indeed the generators of the innovative and experimental development within the field of memorial sculpture and architecture in Yugoslavia, functioning as key organizational platforms that had contributed to the formation of the Yugoslav memorial landscape.

The social network generated and analysed for the purposes of this study is but an initial survey of potential further exploration of the possibilities offered by digital tools. It has

295 For the genesis of the term, see: Ibid, 11 quabic competitions are apt for quantitative and network analysis. The existing network could be expanded both in terms of its quantitative scope - which would require further archival research - and in analysing and quantifying the nature and complexity of entities' interrelations. In more general terms, this study has indicated the analytic potential for using competitions as suitable angles for examining the intersections and overlapping of the fields of art/architecture and politics in the post-war period.

Several clear advantages can be outlined in the results of such an approach to the phenomenon of public competitions for monuments. With substantial knowledge on the historical background of the phenomenon, it enables a rapid shift between micro- and macro-story perspectives. The automatic data calculation and visualization makes all actors, regardless of their symbolic status, equally visible within the network, thus reducing the possibility of biased historiographical approaches. The visualizations can outline collaborative models that lie behind the production of a monuments or memorial complex, making visible the multitude of actors and professions included in this field of production, as well as creative collaborations that have, for various reasons, been forgotten or overlooked. Such an unbiased perspective on the position of individuals within larger social networks contributes to a fuller understanding of the phenomenon, and to the demystification of the role of "artistic genius" in the process of monument making, without undermining the creative potentials of individual artists and architects. Not only does team work become more evident in such representation, but so does the structural position of the "big names" within the network. Their roles in decision-making processes open up yet another critical perspective on the preferred and/or self-declared artistic autonomy of the modernist artist. Among the most rewarding findings of the statistical analyses is the relatively high percentage of women among the awarded participants. However, coupled with their peripheral position within the network structure, these figures contribute to our understanding of the structural invisibility of female contributions to memorial projects. On the other hand, the centrality of some of female entities in the networks opens up further questions regarding their role as gatekeepers in the social network. Such assumptions could, however, only be investigated through a more in-depth analysis and adequate qualification of the nature and quality of the interrelations between various entities.

Finally, as the very structure of this paper manifests, quantitative methods in humanities - regardless of advances in the digital technologies that support them - should be preceded by or built upon a substantial body of knowledge on regarding a certain historical phenomenon, not only so that researchers and readers are able to comprehend the leve of its social, political and cultural complexity but to improve awareness of the multiple narratives and the existence of personal voices hiding behind differently sized and coloured nodes and edges, located in abstract diagrams and maps. *
* I wish to kindly thank my dear colleagues and friends who helped or assisted me in the process of gathering information on federal competitions for Yugoslav monuments: Jelica Jovanović, Mejrema Zatrić, Tamara Bjažić Klarin, Marija Dorđević, Katarina Mitrović, Oleg Romanov, Eleonora Luketić and Ana Kršinić Lozica. I would also like to thank to the reviewers for their valuable comments and suggestions. 
GRAV, Nouvelle Tendance, 1961; http://www.julioleparc. org/grav10.html Accessed 12 March 2017.

"Interview with Emmett Williams: Fluxus Artist Extraordinaire." UMBRELLA, March 1998; Accessed 11 July, 2018. http://colophon.com/umbrella/emmet.html

Itaú Cultural, a digital encyclopaedia of Brazilian culture. Accessed 11 July, 2018. https://www.escritoriodearte.com

Piero Manzōni Foundation. Accessed 26 August, 2018. http://www.pieromanzoni.org

Almir Mavignier personal website. Accessed 17 July, 2018. http://www.mavignier.com/aus_ein.htm

Lidija Merenik, "Before the Art of New Media." Mute, 3 October (2007). Accessed 23 October, 2018. http:// www.metamute.org/editorial/articles/art-new-media

Medosch, Armin. "The Ultimate Avant-garde: New Tendencies and Bit International." The Next Layer (2008). Accessed 26 August, 2018. https://web.archive.org/ web/20121218030835/http://www.thenextlayer.org/ node/731

Meštrović, Matko. "Art and Technology - Yesterday and today." Talk delivered at the XXXII AICA Congress, Japan. 1998. Accessed 8 July, 2018. https://monoskop. org/Matko_Meštrović\#Essays

Frieder Nake, Susi Grabowski. Computers in fine art, aspects of history and aesthetics. Accessed 21 July, 2018. http://www.agis.informatik.uni-bremen.de/LERNEN/Aktuell/webArt/01.pdf

Hans-Ulrich Obrist. "Systematic Thinking by the Late François Morellet". Art (July 2016). Accessed 17 July, 2018. http://www.culturedmag.com/francois-morelle

Poinsot, Jean-Marc. "Pierre Restany: The Letter to Leo Castelli." Critique d'art [En ligne], 22 | Automne 2003 mis en ligne le 27 février 2012, consulté le 30 juillet 2016. URL: http://critiquedart.revues.org/1878; DOI: 10.4000 critiquedart. 1878

Round table discussion "New Tendencies and Architecture: Abstraction, Ambience, Algorithm", Internation Architecture Exhibition, Venice, 8 August, 2014. Accessed 18 May, 2016. http://www.mavignier.com

Smithsonian American Art Museum. Nam Jun Paik Collection. Interview of Artist Otto Piene. Accessed 21 July, 2018. https://americanart.si.edu/research/paik/re sources/piene ww.escritoriodearte.com/artista/alexander-wollner/

Zero Foundation. Accessed 26 August, 2018. http:// www.zero.com

\section{SANJA HORVATINČIĆ}

Between Creativity and Pragmatism: A Structural

Analysis and Quantitative Survey of Federal

Competitions for Yugoslav Monuments and

Memorial Complexes (1955-1980)

pp. 124-165.

[Sekretarijat Izvršnog odbora Odbora za izgradnju spomenika na Petrovoj gori]. "Tko gura privatni interes". Vjesnik March 23, 1975.

Andersson, Jonas E., Gerd Bloxham Zettersten, and Magnus Rönn "Editors' Comments." In Architectural Competitions - Histories and Practice, edited by Jonas E. Andersson, Gerd Bloxham Zettersten, and Magnus Rönn, 7-11. The Royal Institute of Technology and Rio Kulturkooperativ, 2013.

Baković, J. Nikola. "Konkurs za izgradnju Spomen-parka u Čačku iz 1962. godine " Izvornik. Građa međuopšinskog istorijskog.

Baković, J. Nikola. "Konačan odabir idejnog rešenja za projekat Spomen-parka u Čačku." Izvornik. Građa međuopštinskog istorijskog arhiva Čačak 33 (2017): 315-342.

Barjaktarević, Bogoljub. "Podići ili ne podići. O sudbini somen-obiljěja rudarima u Labinu”. Danas October 12, 1982.

Baylon, Mate. "Javni arhitektonski natječaji u Beogradu između dva rata." Čovjek i prostor: arhitektura, kiparstvo, slikarstvo i primijenjena umjetnost, vol. 226, no. 26 (1975): 10-13.

Bernik, Stane. "Trije natečaji." Sinteza. Revija za likovno kulturo, vol. 2, no. 7 (October 1967): 38-43.

Bihalji-Merin, Oto, ed. Jajinci: povodom konkursa za idejni projekt spomenika žrtvama fašizma, Jajinci Jugoslavija. Belgrade: Publicističko-izdavački zavod Jugoslavija, 1958

Bjažić Klarin, Tamara. Arhitektonski i urbanistički natječaji između dva svjetska rata (1918-1941) - slučaj Zagreb. Zagreb: Institute of Art History, 2018.

urstow, Robert. "Western European Modernism in the Service of American Cold-War Liberalism." In
Europe, edited by Ljiljana Kolešnik, 37-56. Zagreb: Croatian Society of Art Historians, 2004.

Čepić, Mirko. "Spomenik NOBe u Mariboru." Čovjek prostor: arhitektura, kiparstvo, slikarstvo i primijenjen umjetnost, no. 53 (September 1956).

Chupin, Jean-Pierre, Carmela Cucuzzella and Bechara Helal (eds). Architecture Competitions and the Production of Culture, Quality and Knowledge: An Internationa Inquiry. Potential Architecture Books Inc., 2015.

Davidović, Jelena. "Tri spomenika u spomen-parku 'Kragujevački oktobar'." Šumadijski anali: časopis za istorijografiju, arhivistiku i humanističke nauke, vol. 2 , no. 2 (2006): 236-255.

Dragičević, Zana. "Spomenik na Petrovoj gori - prilog istraživanju i revalorizaciji." Anali Galerije Antuna Augustinčića, no. 32-33; 34-35 (2015): 385-404.

Franković, Eugen. "Spomenik Titu u Zagrebu - kakav gdje? Izraz epohe". Vjesnik March 8, 1985.

Frković, Josip. "Memorijalac spašava privatnik". Večern list September 30, 1989

Gamulin, Grgo. "Nesporazum o spomeniku. U povodu odgovora arh. Igora Toša". Hrvatsko Sveučilište October 13, 1971.

Gamulin, Grgo. "Spomenik na Kozari." Život umjetnosti, no. 15/16 (1971): 129-142.

Gamulin, Grgo. "Znak u vremenu." Dometi : književnost kultura, društvena pitanja, no. 3-4 (1970).

Horvatinčić, Sanja. "Monuments Dedicated to Labor and the Labor Movement in Socialist Yugoslavia." Et nološka tribina : godišnjak Hrvatskog etnološkog društva, vol. 44, no. 37 (2014), 153-168.

Horvatinčić, Sanja. "Povijest nemogućeg spomenika izgradnja spomenika žrtvama fašizma u Jajincima." Anali Galerije Antuna Augustinčića, no. 32-33; 34-35 (2015): 261-282.

Horvatinčić, Sanja. Spomenici iz razdoblja socijalizma u Hrvatskoj - prijedlog tipologije. PhD Thesis. Zadar University of Zadar, 2017.

I.O. "Pomanjkanje etičkog i profesionalnog odnosa" Vjesnik January 8, 1983.

Janković, Nataša. "Architectural Terri(s)tories: Jajinci Memorial Park in Belgrade." AM Journal, no. 12 (2017): 81-98.
Joyeux-Prunel, Béatrice. “ARTL@S: A Spatial and Trans-national Art History Origins and Positions of Research Program," Artl@s Bulletin, Vol. 1, Iss. 1 (2012): Article 1.

Judt, Tony. Postwar: A History of Europe Since 1945. New York: The Penguin Press, 2005.

Karge, Heike. Sećanje u kamenu - okamenjeno sećanje. Belgrade: XX Vek, 2014

Kazimirović, Vasa. "Bogdan Bogdanović: Umijesto strave opredijelo sam se za život”. Vjesnik July 3, 1966.

Klaić, Smiljan. "Natječaj za arhitektonsko-pjezaž no-skulpturalno rješenje spomenpark u Sarajevu. Čovjek i prostor: arhitektura, kiparstvo, slikarstvo primijenjena umjetnost, no. 148 (July 1958): 5.

Kolacio, Zdenko. "'Kova je naša.' Opći jugoslavenski natječaj za uređenje spomen-prostora rudaru, Labin 1980." Čovjek i postor: mjesečnik Saveza arhitekata Hrvatske, no. 340-341(1981): 10-11.

1981: 6.

ko. "Rudaru i borcu". Vjesnik June 23 ,

Kolacio, Zdenko. "Spomenik na Makljenu. Osvrt na natječaj." Čovjek i prostor: monthly for architecture painting, sculpture, design and applied arts, no. 297 (1977): 12-13.

Lipstadt, Helene. The Experimental Tradition: Essays on Competitions in Architecture. Princeton Architectura Pr. 1989

Ljubičić, Marina. Kozara, spomenik slobode Memorijalnimuzej na Mrakovici. Exhibition catalogue. Prijedor: Nacionalni park “Kozara”, 2016.

M.B. "Spomenik na Petrovoj gori 1976". Vjesnik November 23, 1973.

Macura, Milorad. "Zapisi na marginama pravilnika o konkursima." Arhitektura - Urbanizam: časopis za arhitekuru, urbanizam, primenjenu umetnost industrijsko oblikovanje, no. 16 (1962): 51.

Malmberg, Catherine, ed. The Politics of Design: Competitions for Public Projects. Princeton, NJ: Policy Research Institute for the Region, 2006.

Marter, Joan. "The Ascendancy of Abstraction for Public Art: The Monument to the Unknown Political Prisoner Competition." Art Journal. Sculpture in Postwar Europ and America 1945-1959, vol. 53, no. 4 (1994): 28-36. 

pćem, 127-128. Zagreb: DAF, 2005.

n.n. “Konkurs" (Opštejugoslavenski anonimni konkurs za Meštrović, Matko. "Idejni projekti za spomenik u izraduidejnog rešenja grobnice i prostorau spomen-parku Kamenskom (1961)". In Matko Meštrović. Od pojedi- u Kragujevcu). Arhitektura - Urbanizam. №. 40 (1966): 56. načnog općem, 123-125. Zagreb: DAF, 2005.

Minić, Oliver. "Konkurs za spomenik palim borcima Čačku." Arhitektura - Urbanizam: časopis za arhitekuru, urbanizam, primenjenu umetnost $i$ industrijsko oblikovanje, no. 17 (1962): 46, 47; 52

Mitrović, Katarina. "Intelektualac u socijalističkoj umjetnosti: spomenik Moši Pijadi u Beogradu_djelo Brana Ružića (Intellectual in Socialist Art: Branko Ružić's Monument to Moša Pijade in Belgrade)." Peristil, no. 60 (2017): 129-146.

Mlikota, Antonija. "Natječaj za spomenik drugu Titu i vekovnoj borbi Zadra za slobodu iz 1982. goditu." Anali Galerije Antuna Augustinčića, no. 32-33; 34-35 (2015): 299-321.

Murwaska-Muthesisus, Katarzyna. "Oskar Hansen and the Auschwitz Countermemorial, 1958-1959." In Figuration/Abstraction: Strategies for Public Sculpture in Europe, 1945-1968, edited by Charlotte Benton, 193-211. London: Ashgate Publishing Limited; Henry Moore Institute, 2004

n.n. "Da mrtav junak živima kazuje". Politika Ekspres February 1, 1981

n.n "Konkurs" (Odbor za podizanje spomenika Mosi Pijade). Arhitektura - Urbanizam: časopis za arhitekuru, urbanizam, primenjenu umetnost i industrijsko oblikovanje, no. 43 (1967): 61.

n.n "Spomen-park u Kragujevcu." Arhitektura - Urbanizam: časopis za arhitekuru, urbanizam, primenjenu umetnost $i$ industrijsko oblikovanje, no. 44 (1967): 50.

n.n. "Idejno rješenje 'Parka prijateljstva' u Beogradu." Čovjek i prostor: arhitektura, kiparstvo, slikarstvo i primijenjena umjetnost, no. 157 (April 1966): 6, 9.

n.n. "Iz programa za idejno rešenje spomen.parka Jajinci." Arhitektura - Urbanizam: časopis za arhitekuru, urbanizam, primenjenu umetnost $i$ industrijsko oblikovanje, no. 86-87 (1982): 78-81.

n.n. "Izvještaj Komisije o izboru natječajnih radova za Spomenik podbjede narodne revolucije u Kamenskom o nagrađenim radovima". Vjesnik January 15, 1961.

n.n. "Javni natječaj za idejno rješenje spomenika Edvardu Kardelju". Borba June 21, 1979: 8. n.n. "Konkurst za izrdu idejnog projekta spomenika palim borcima NOVJ na Sremskom frontu 1944. 1945. Godine." Arhitektura - Urbanizam: časopis za arhitekuru, urbanizam, primenjenu umetnost industriijko oblikovanje, no. 74-77 (1975): 148-150.

n. "Konstitutiran dbor za gradnju spomenika na Petrovoj gori". Vjesnik March 18, 1973.

n.n. "Natječaj za izradu idejnog rješenja spomenika na Petrovcu u Petrovoj gori." Čovjek i prostor: arhitektura, (1971): 16-20

n.n. “Natječaj za izradu idejnog rješenja spomenika seljakčkoj buni 1573. godine u Hrvatskoj i Sloveniji u Gornjoj Stubici." Čovjek i proctor: arhitektura, kiparstvo, slikarstvo i primijenjena umjetnost, no.

n.n. "Rad V. Bakića najprihvatljiviji”. Vjesnik June 29, 1977.

n.n. "Rezultati konkursa za spomen park na Vracima." ARH: Časopis društva arhitekata Sarajevo, no. 9, vol.

n.n. "Rezultati natječaja za idejno prostorno-arhitektonsko, skulpturalno i hortikulturno rješenje dela uže Borba January 2, 1980.

n.n. "Rezultati općejugoslavenskog anonimnog natječaja za izradu spomen obilježa 'Borbi naroda južnog Banata u Deliblatkoj peščari”. Čovjek i umjetnost, no. 234 (September 1972).

n.n. "Rezultati opštejugoslavenskog anonimnog nonkursa za idejnoubr Spomen parka sa zrtvama palim oktobara 1941. Godine u Kraljevu." Arhitektura - Urbanizam: časopis za arhitekuru, urbanizam, primenjenu umetnost $i$ industrijsko oblikovanje, no. 61-62 (1970): 134

n.n. "U Zagrebu otvorena izložba 'Predlog spomenika Jasenovac'. Četvrti jul March 19, 1963.

n.n. "Žiri doneo odluku za idejno rešenje spomen-parka". Ibarske novosti December 11, 1970. kiparstvo, slikarstvo i primijenjena umjetnost, no. 222 211(1970):14-16. 3 (1966): 5-32. memroialne zone Spomen-područja Donja Gradina". prostor: arhitektura, kiparstvo, slikarstvo i primijenjena
Odbor za dovršenje spomen-parka Jajinci u Beogradu. "Konkurs za idejno rešenje Spomen-parka Jajinci Beogradu." Arhitektura - Urbanizam: časopis za arhitekuru, urbanizam, primenjenu umetnost i industrijsko oblikovanje, no. 83-84 (1980): 91.

OMN. "Idejno rješenje za izgradnju I uređenje 'Parka prijateljstva' u Beogradu." Arhitektura - Urbanizam: časopis za arhitekuru, urbanizam, primenjenu . 87-88.

Ortega, Nuria Rodríguez. "Digital Art History: An Examination of Conscience." Visual Resources: An International Journal of Documentation, vol. 29, no. 1-2 (2013): 129-133.

Pasinović, Antoaneta. "Možda opet na treći način". Vjesnik July 20, 1978.

Pavlaković, Vjekoslav. "Slojevit a nedefiniran prostor". Vjesnik January 8, 1983.

Pavlović, Bora. "Još jednom oko rešenja spomen-parka u Jajincima". Borba Febraury 26, 1981.

Pravilnik o konkursima iz oblasti arhitekture i urbanizma. Belgrade: Savez arhitekata Jugosalvije, 1968.

Radojković, Radmila. “Dušan Džamonja: Spomenik - izraz iskustva i povjerenja". Četvrti jul 15 January 1980, 14

Radojmović, Radmila. "Kosta Angeli Radovani: Izgubljeno poverenje u konkurse?". Četvrti jul 22 January 1980, 12.

Rajčević, Uglješa. Zatirano i zatrto. O uništenim srpskim spomenicima (Vol. I and Vol. II). Novi Sad: Prometej, 2001

Ravnikar, Edvard. "Konkurs za spomenik revolucije u Ljubljani." Arhitektura - Urbanizam: časopis za arhitekuru, urbanizam, primenjenu umetnost $i$ industrijsko oblikovanje, no. 17 (1962): 48, 49; 57.

Ridle, Andrea, and Lukas Schretter, eds. Das internacionale Mahnmal von Nandor Glid. Idee, Wettbewerbe Realisirung. Berlin: Metropol-Verlag, 2015.

S. Ab. "Natječaj za spomenik Titu i revoluciji. Sedam neuspjelih radova". Vjesnik December 12, 1982.

Schreibman, Susan, Ray Siemens, and John Unsworth. A New Companion to Digital Humanities. John Wiley \& Sons, 2016. a hesis Bel Isue of Autonomy of Architecture. PhD Architecture, 2016.

Škunca, Josip. "Antun Augustinčić: Jedanput natječa drugi put ne". Vjesnik December 31, 1970.

Spomen područje Dotrščina. Natječajni radovi. Zagreb: Skupština grada Zagreba; Komisija za uređenje spomen-područja Dotrščina, 1980.

Stanić, Stevan. "Bez marame na licu". Nin Febrary 8 1981: $28-29$

Stanić, Stevan. "Posle konkursa: Bez priča i potpričica" Nin January 25, 1981: 36-68.

Stojanović, Branislav. "Konkurs za spomenik Kosmajskom partizanskom odredu." Arhitektura - Urbanizam. No. 56-57 (1969): 33

Stojanović, Bratislav. "Spomenik Marksu i Engelsu Beogradu." Godišnjak Muzeja grada Beograda, vol. II (1956): 553-588.

Surla, Zoran, ed. Sremski front od bitke do spomenik Po kazivanju arhitekte Miroslava Krstonošića i Bogdana Tankosića zabeležio Zoran Surla. Novi Sad: Atelje Krstonošić, 2017.

Toš, Igor. "Natječaj - samovolja ili društveni dogovor?" Vjesnik March 16, 1975

Toš, Igor. “Pokušaj prebacivanja odgovorinosti”. Vjesnik April 3, 1975.

Tušek, Darovan. Arhitektonski natječaji u Splitu 1945 1995. Split: Društvo arhitekata Splita; Građevins fakultet Sveučilišta u Splitu, 1996.

Vasiljković, Kosta. "Sublimirajući pijetet protiv ridajućeg 'valjanja u suzama'". Oko January 22, 1981: 20.

Wenzler, Fedor. "Natječaj za spomenik pobjede na Srijemskom frontu." Čovjek i prostor: arhitektura, kiparstvo, slikarstvo i primijenjena umjetnost, no. 268 (July 1975): 8-11.

Wenzler-Halambek, Mira. "Centralni park novog Skoplja." Hortikultura: Jugoslavenski časopis za privredna praktična I teoretska pitanja iz kortikulture, vol. XXXV, no. 3 (September 1968): 1-3.

Živković, Mirjana. "Javna rasprava o konkursu za Jajince. Privid protivljenja". Politika December 17, 1980. 
ŽELJKA TONKOVIĆ, SANJA SEKELJ

Duality of Structure and Culture: A Network

Perspective on the Independent Cultural

Scene in Zagreb and the Formation of the WHW Curatorial Collective

pp. 166-192

Charmaz, Kathy. Constructing Grounded Theory: A Practical Guide through Qualitative Analysis. LondonThousand Oaks-New Delhi: Sage Publications, 2006.

Cvjetičanin, Biserka, and Vjeran Katunarić, eds. Kulturna politika Republike Hrvatske: nacionalni izvještaj. Zagreb: Ministarstvo kulture Republike Hrvatske - Institut za međunarodne odnose, 1998.

Herz, Andreas, Peters, Luisa, and Inga Truschkat. "How to do qualitative structural analysis: the qualitative interpretation of network maps and narrative interviews." Forum: Qualitative Social Researc (2015).
interviews. Forum: Qualitative Social Research 16/1

Janković, Vesna, and Nikola Mokrović, eds. Antiratna kampanja 1991. - 2011. Neispričana povijest. Zagreb: Documenta - Centar za suočavanje s prošlošću Antiratna kampanja, 2011.

Kadushin, Charles. Understanding Social Networks. epts and Findings. New York: Oxfor University Press, 2012

Knoke, David, and Song Yang. Social Network Analysis. Thousand Oaks: Sage, 2008 [1982].

Medak, Tomislav, and Petar Milat, eds. Prospects of Arkzin / Izgledi Arkzina. Zagreb: Arkzin - Multimedijalni institut, 2013.

Mische, Ann. "Cross-talk in movements: rethinking the culture-network link." In Social Movements and Networks: Relational Approaches to Collective Action, edited by Mario Diani and Doug McAdam, 258-280. New York: Oxford University Press, 2003.

Mische, Ann. "Relational sociology, culture, and agenMische, In The SAGE Handbook of Social Network Analysis, edited by John Scott and Peter J. Carrington, 80-97. Los Angeles-London: Sage, 2011.

Naša priča: 15 godina ATTACK!-a. Zagreb: Autonomni kulturni centar, 2013.

Pachucki, Mark A., and Ronald L. Breiger. "Cultural holes: Beyond relationality in social networks and culture." Annual Review of Sociology 36 (2010): 205-224.
Pejović, Katarina. "Bakal, Boris: navigator izmještanja i diskontinuiteta - portret multimedijalnog umjetnika." Up \& Underground 7/8 (2004): 18-33.

Stubbs, Paul. "Networks, Organisations, Movements Narratives and Shapes of Three Waves of Activism in Croatia." Polemos 15 (2012): 11-32.

Vidović, Dea. “Nezavisna kultura u Hrvatskoj (1990. 2010.)." In Dizajn i nezavisna kultura, edited by Maroje Mrduljaš and Dea Vidović, 9-39. Zagreb: Savez udruga Klubtura - UPI 2M PLUS d.o.o. - KURZIV, 2010.

Vidović, Dea. "Taktičke prakse u pristupima lokalnim kulturnim politikama u Zagrebu." Život umjetnosti 86 (2010): 22-35.

Wasserman, Stanley, and Katherine Faust. Socia Network Analysis. Methods and Applications. New York: Cambridge University Press, 2009.

White, Harrison C. Identity and Control: How Socia Formations Emerge. Princeton: Princeton University Press, 2008.

\section{ONLINE SOURCES}

Bauer, Una. "Crvene niti kontinuiteta i kolaboracije - intervju s kustoskim kolektivom WHW." Kulturpunkt, March 9, 2010. Accessed July 25, 2018. huturp kulturpunkt hr/content/crvene-niti-kontinuiteta-i-kolaboracije-0

Clubture. Accessed August 14, 2018. http://www.club ture.org/

Galerija ŠKUC, "Why MSE-projects?." Accessed October 4, 2018. http://www.galerijaskuc.si/v2/why-mseprojects/

Multimedijalni institut, "Zagreb - kulturni kapital Evrope 3000." Accessed August 14, 2018. www.mi2.hr/hr/suradnje/zagreb-kulturni-kapital-evrope-3000/

Sandić, Srđan. "Kritičar kao dionik, zagovarač i medijator - intervju s Markom Golubom." Vizkultura, March 9, 2016. Accessed July 25, 2018. https://vizkultura.hr/ kriticar-kao-dionik-zagovarac-i-medijator/

Spieker, Sven. "Interview with WHW Collective." ART Margins, July 5, 2011. Accessed July 25, 2018. http:// www.artmargins.com/index.php/5-interviews/635-interview-with-whw-collective-zagreb

Vidović, Dea. "Život s WHW-om - intervju s Dejanom Kršićem." Kulturpunkt, August 16, 2010. Accessed July 25, 2018. https://www.kulturpunkt.hr/content/\%C5\%BEivot-s-whw-om
WHW, "Što, kako i za koga, povodom 152. godišnjice Komunističkog manifesta." Accessed July 25, 2018. http://www.whw.hr/novosti/index.html

\section{UNPUBLISHED SOURCES}

Interview 1, interview by Ivana Meštrov and Željka Ton ković, November 3, 2015.

Interview 2, interview by Ivana Meštrov and Željka Tonković, November 24, 2015

Interview 4, interview by Ivana Meštrov and Željka Tonković, November 25, 2015

Interview 11, interview by Ivana Meštrov, December 22, 2015.

Interview 15, interview by Željka Tonković, March 17 2016.

Interview 16, interview by Sanja Horvatinčić and Željka Tonković, March 29, 2016.

Interview 17 , interview by Ivana Meštrov and Željka Tonković, March 29, 2016

Interview 18 , interview by Sanja Sekelj and Željka Tonković, December 6, 2016.

Interview 20, interview by Sanja Sekelj, December 8 2016.

Interview 21, interview by Sanja Sekelj and Željka Tonković, March 6, 2017.

Interview 25, interview by Sanja Sekelj and Željka Tonković, April 7, 2017. 